\title{
Review
}

\section{Tailored zeolites for the removal of metal oxyanions: Overcoming intrinsic limitations of zeolites}

\author{
Hugo Figueiredo*, Cristina Quintelas \\ CEB-Centre of Biological Engineering, University of Minho, Campus de Gualtar, 4710-057 Braga, Portugal
}

\section{H I G H L I G H T S}

- First review manuscript singly focusing on the interaction of zeolites with metal oxyanions.

- The focus on chromium and arsenic oxyanions offers the covering of a wide array of zeolite modification technologies.

- Detailed description of the zeolite modification technologies that have been successfully employed to date.

- Global overview of the experimental results obtained with the modified supports, with given considerations on the diverse aspects of heavy metal treatment.

\section{A R T I C L E I N F O}

\section{Article history:}

Received 5 February 2014

Received in revised form 24 March 2014

Accepted 9 April 2014

Available online 18 April 2014

\section{Keywords:}

Zeolite

Chromium

Arsenic

\section{G R A P H I C A L A B S T R A C T}

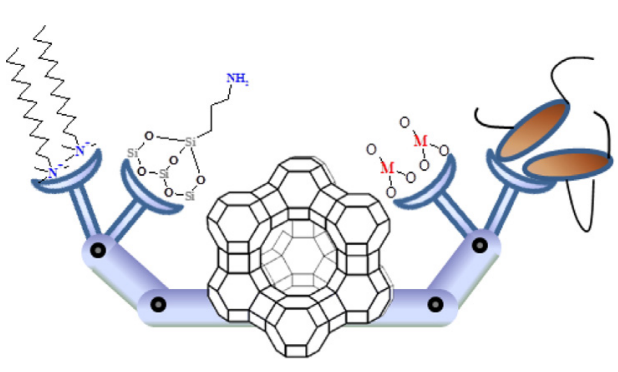

\begin{abstract}
A B S T R A C T
This review aims to present a global view of the efforts conducted to convert zeolites into efficient supports for the removal of heavy metal oxyanions. Despite lacking affinity for these species, due to inherent charge repulsion between zeolite framework and anionic species, zeolites have still received considerable attention from the scientific community, since their versatility allowed tailoring them to answer specific requirements. Different processes for the removal and recovery of toxic metals based on zeolites have been presented. These processes resort to modification of the zeolite surface to allow direct adsorption of oxyanions, or by combination with reducing agents for oxyanions that allow ion-exchange with the converted species by the zeolite itself. In order to testify zeolite versatility, as well as covering the wide array of physicochemical constraints that oxyanions offer, chromium and arsenic oxyanions were selected as model compounds for a review of treatment/remediation strategies, based on zeolite modification.
\end{abstract}

(C) 2014 Elsevier B.V. All rights reserved.

\section{Contents}

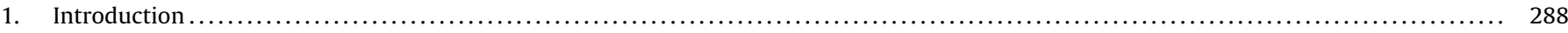

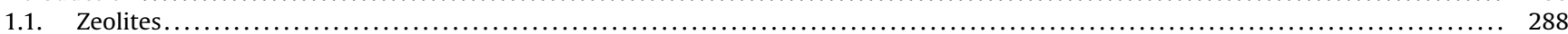

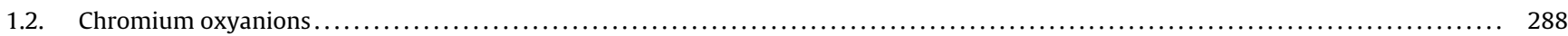

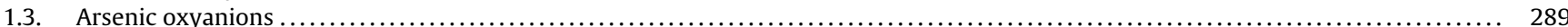

\footnotetext{
* Corresponding author. Tel.: +351253604400.

E-mail addresses: hsfigueiredo@deb.uminho.pt (H. Figueiredo), cquintelas@deb.uminho.pt (C. Quintelas).
} 


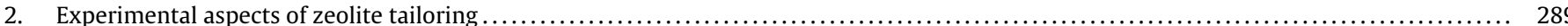

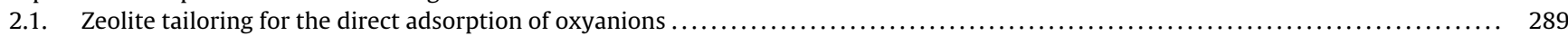

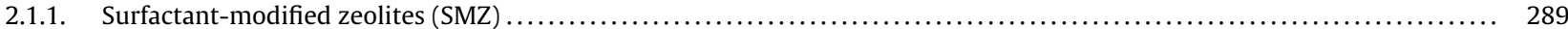

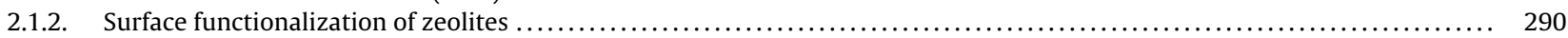

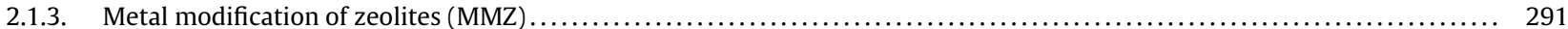

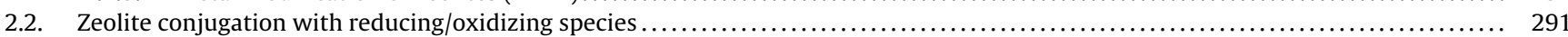

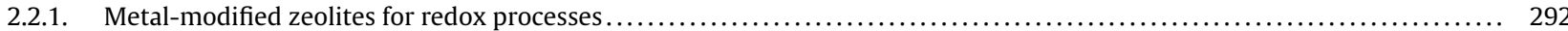

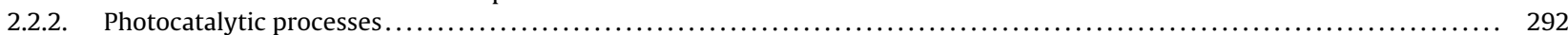

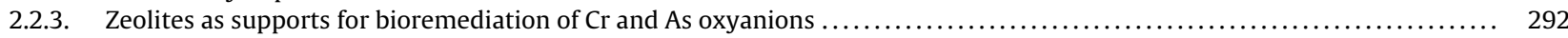

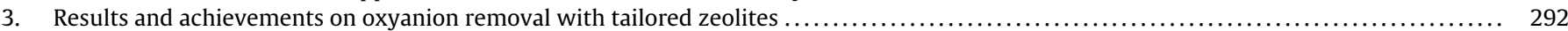

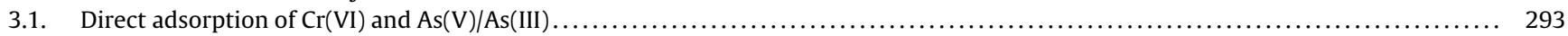

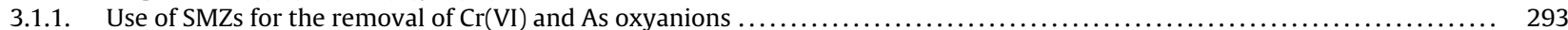

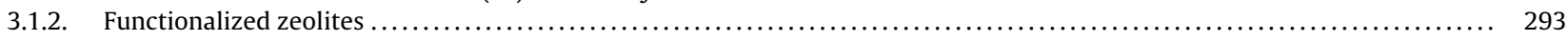

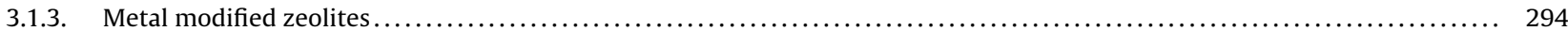

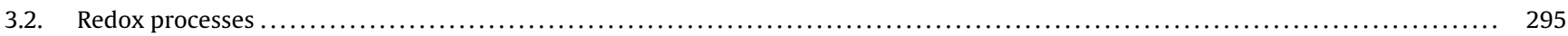

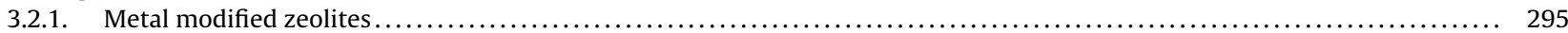

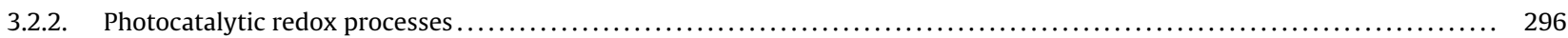

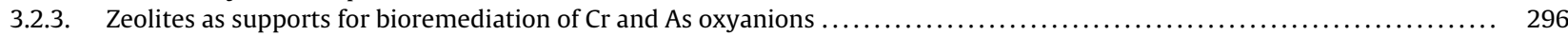

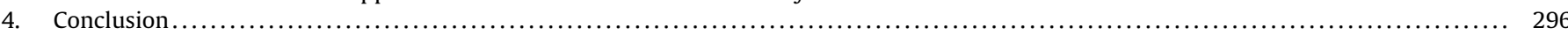

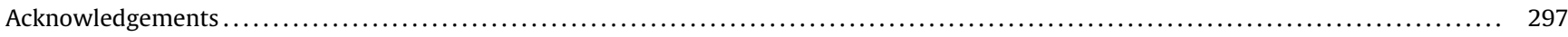

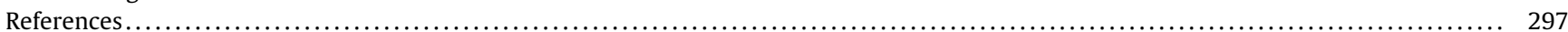

\section{Introduction}

Heavy metal contamination of the environment is a well-known concern. The discharge of these pollutants into aqueous streams is a direct result of human activity, mainly industrial [1]. Although some metals are essential to the enzymatic processes of aerobic or anaerobic organisms [2], high concentrations of the same can be toxic to lethal. Also, as heavy metals accumulate in the organisms and persist through their food chain, they ultimately present a risk for human health.

Numerous technologies have been developed for the treatment of heavy metal contamination, in aqueous medium or in soils. Ionexchange and adsorption are amongst the most referred processes for this treatment [3]. Given the increasing environmental and economical awareness, development efforts for new technologies must bear in mind the potential for recovery-reuse capability, in a bid to decrease demand on processing of mineral ores and ultimately reducing manufacturing costs by allowing reutilization of otherwise discarded spent materials [4].

Zeolites have been proposed by some authors to be an efficient and economical resource for the treatment of general heavy metal contamination of effluents [3-6]. Their ion-exchange and adsorption capacities endow these supports with the ability to recover most cationic species from solution. Conversely, zeolites present very low to negligible affinity for the exchange of anionic compounds. Nevertheless, their physicochemical properties also render zeolites quite versatile materials, and many researchers found interest in these supports and conducted efforts to tailor zeolites in order to allow the removal of anionic compounds. These tailored materials have found application on the removal of toxic metal oxyanions, such as chromate or arsenate [7], radioactive uranyl ions [8], as well as other non-metallic anionic species such as iodides [9], phosphates [10] or nitrates [11].

This paper presents details of the strategies that have been developed to overcome the natural limitation of zeolites to the removal of oxyanions. The focus is given on the treatment of $\mathrm{As}(\mathrm{III}), \mathrm{As}(\mathrm{V})$ and $\mathrm{Cr}(\mathrm{VI})$ compounds, some of the most commonly found oxyanions in metal-contaminated sites. The choice on these compounds is justified as they cover some interesting differences between them, which are also transported to some extent to the application and performance of tailored zeolites.

A brief introduction to zeolites and the mentioned oxyanions will be followed by a detailed description of the functionalization procedures, ending on a comparison of achievements of the different tailoring processes on the removal/treatment of chromium and arsenic oxyanions.

\subsection{Zeolites}

Zeolites are highly crystalline aluminosilicate materials, consisting of either Si or Al atoms interconnected via oxygen bridges. Si and Al are also referred as "T atoms", as they are the center of tetrahedral $\mathrm{SiO}_{4}$ or $\mathrm{AlO}_{4}$ structures. These tetrahedra are the building blocks forming the several crystalline lattice structures known so far, from either naturally occurring or specifically designed synthetic zeolites. Their intricate structural arrangement is also responsible for the high specific surface area of these materials, which present figures exceeding $700 \mathrm{~m}^{2} / \mathrm{g}$ [12]. This is a key factor for the excellent adsorption and catalytic properties of these materials.

Since aluminum has a valence of +3 and silicon +4 , isomorphic framework substitution of $\mathrm{Si}$ by $\mathrm{Al}$ originates a charge deficit that is responsible for the need of charge-balancing cations, in order to maintain the neutrality of the zeolitic network [13]. Common charge-balancing cations are alkaline or rare-earth metals like $\mathrm{Na}^{+}$, $\mathrm{K}^{+}, \mathrm{Mg}^{2+}$ or $\mathrm{Ca}^{2+}$, which are electrostatically bound to the $\mathrm{Al}$ atoms [14]. The mobility of these species promotes the ion-exchange capability of zeolites for cationic species. The ion-exchange capacity of a zeolite is dependent on the $\mathrm{Si} / \mathrm{Al}$ ratio of the framework, where a higher Al content will correspond to a higher content of charge-balancing cations, which in turn will increase the overall ion-exchange capacity of the zeolite [15]. Naturally occurring zeolites present high $\mathrm{Al}$ content, with $\mathrm{Si} / \mathrm{Al}$ ratios typically ranging from 1 to $6[16]$.

\subsection{Chromium oxyanions}

Chromium is an important industrial compound, mainly used in electric plating, refining, printing and dying industries $[17,18]$. It is one of the most common inorganic contaminants present in groundwater of hazardous waste sites, in the form of hexavalent chromium, one of the most toxic priority pollutants [18-20].

In aqueous medium, this transition metal can be found in different oxidation states, the most common are the trivalent and hexavalent states [21], being $\mathrm{Cr}(\mathrm{III})$ the most stable. Divalent $\mathrm{Cr}(\mathrm{II})$ is also known to be stable in oxygen-free conditions, as it is strongly reducing [22]. Trivalent chromium is an essential trace element for the metabolism of glucose and lipids [20]. Most $\mathrm{Cr}$ (III) compounds 
present very low solubility at neutral or physiological $\mathrm{pH}$, therefore considered to bear low toxicity to cells [23]. $\mathrm{Cr}(\mathrm{VI})$ forms much more soluble species, being extremely mobile in soils or groundwater [24,25]. Also, the external cell structure is more permeable to $\mathrm{Cr}(\mathrm{VI})$ than for the case of $\mathrm{Cr}(\mathrm{III})$ [26]. The carcinogenic and/or mutagenic effects of $\mathrm{Cr}(\mathrm{VI})$ arise from the combination of its mobility in cellular structures and high redox potential. $\mathrm{Cr}(\mathrm{VI})$ permeates cellular walls and, once in the cellular cytoplasm, is converted into $\mathrm{Cr}(\mathrm{III})$, which can bind covalently to biomolecules such as DNA [21].

$\mathrm{Cr}(\mathrm{VI})$ is commonly found as chromate or dichromate anions [27]. This speciation is related to $\mathrm{pH}$ and concentration [28], where chromate is predominant at very low $\mathrm{pH}$. The negative charge of chromate and dichromate is responsible for their poor adsorption in soils or most mineral structures, which explains the great mobility of $\mathrm{Cr}(\mathrm{VI})$ in these media.

Since most contaminant metals form cationic species in aqueous media, technologies designed for the treatment of common metal contamination may suit $\mathrm{Cr}$ (III) but lack the flexibility for the anionic $\mathrm{Cr}(\mathrm{VI})$ species. The most common treatment procedures for $\mathrm{Cr}(\mathrm{VI})$ include reduction-precipitation, liquid-solid transfer, precipitation-flocculation or concentration [17]. Most of these technologies are disposal-type, so efforts have been conducted on the research for recovery-reuse procedures, in order to address cost-effectiveness and decrease demand on chromium ore resources.

\subsection{Arsenic oxyanions}

Arsenic is the 20th most abundant element of the Earth's crust and contamination of aqueous sources is known to occur naturally, although human activity also contributes to the release of this metal into the environment [29,30]. It has found application in several industries, namely mining, glassmaking, electronics, wood preservation and pharmaceutics [31]. Apart from the natural contamination sources, use of arsenic in agricultural products such as fungicides, herbicides and insecticides has added to the contamination of soils and underground water sources. Arsenic is known to be carcinogenic and its contamination, both natural or anthropogenic, is a known cause for concern, especially as there are widespread reports of populations depending on As-contaminated water sources [29,32].

Arsenic is a metalloid with similar chemistry to phosphor and antimony [33]. In environmental conditions, it is found in the trivalent and pentavalent oxidation states, both forming oxyanions. Oxic environments favor the $\mathrm{As}(\mathrm{V})$ inorganic acid species, ranging from $\mathrm{H}_{3} \mathrm{AsO}_{4}$ at $\mathrm{pH}$ below 2 to the arsenates $\mathrm{H}_{n} \mathrm{AsO}_{4}{ }^{n-3}(n \leq 2)$, where $\mathrm{AsO}_{4}{ }^{3-}$ is found at pH higher than 10. As(III) compounds are normally found in anoxic and/or reducing environment such as underground waters, typically as $\mathrm{H}_{3} \mathrm{AsO}_{3}$ at $\mathrm{pH}$ below 9, or the arsenite forms $\mathrm{H}_{n} \mathrm{AsO}_{3}{ }^{n-3}(n \leq 2)$ for higher $\mathrm{pH}[32,33]$. Some bioprocesses also contribute to the speciation of $\mathrm{As}(\mathrm{V})$ to $\mathrm{As}(\mathrm{III})$, as bacteria can promote reduction and methylation of arsenic as a defense to its toxicity. Also, intra-cellular $\mathrm{As}(\mathrm{V})$ reduction into As(III) may give rise to free radicals which promote damage to cellular structures, and arsenite in known to inhibit several enzymes [31]. However, some bacteria are known to use arsenic in their energy metabolism, since arsenate is similar to phosphate and may replace the latest in biomolecules.

Comparatively to $\mathrm{Cr}(\mathrm{VI})$, the negative charge of the different arsenite or arsenate species requires specific treatment processes. As $(\mathrm{V})$ is considered less toxic as it adsorbs more strongly to solid surfaces than $\mathrm{As}(\mathrm{III})$, so oxidation-precipitation or oxidation-coagulation/flocculation processes are typically employed for the treatment of As-containing wastewaters or for in situ remediation of soil contamination [32,34,35]. Other processes include ion-exchange in specific resins, membrane processes and adsorption on iron-based materials.

\section{Experimental aspects of zeolite tailoring}

Due to their ion-exchange capacity, zeolites have found widespread use in research studies related to the removal of metal contaminants in general $[4,6]$. Studies on the removal of $\mathrm{Cr}$ and $\mathrm{As}$ have also been conducted.

For the removal of $\mathrm{Cr}(\mathrm{III})$, zeolites have been widely considered to be good supports for the direct removal of these species, in either natural or synthetic form, and in the presence of other competing metal species [36-39]. Studies on the removal of $\mathrm{Cr}(\mathrm{VI})$ present a different nature from other cationic metal ions removal processes. Zeolites are unable to perform direct ion exchange of $\mathrm{Cr}(\mathrm{VI})$ compounds, as charge repulsions from the negatively charged framework limits its permeability to anions [40]. This limitation was witnessed by several authors, in both natural and synthetic zeolites $[24,41]$. Arsenate ions present some differences toward $\mathrm{Cr}(\mathrm{VI})$, as unmodified zeolites have some affinity for arsenic oxyanions (detailed in Section 3). Nevertheless, studies on the usage of zeolites for the removal of $\mathrm{Cr}$ and As oxyanions generally present indirect methodologies, where zeolites are previously modified in order to overcome their limitation for negatively charged ions.

From the different methodologies proposed, a separation into two distinct processes is possible: processes that involve zeolite surface functionalization for direct oxyanion adsorption (discussed in Section 2.1), and processes involving redox reactions of $\mathrm{Cr}$ or As and subsequent retention by the zeolite-based system (discussed in Section 2.2).

\subsection{Zeolite tailoring for the direct adsorption of oxyanions}

The adsorption of various anions on tailored zeolites has been achieved. In order to allow adsorption to occur, tailoring of the zeolite surface is required as to modify the negative zeta potential that repels these compounds. Two main processes have been successfully employed: deposition of surfactants on the zeolite surface (Section 2.1.1), and grafting molecules with affinity for negative ions onto the zeolite (Section 2.1.2). Additionally, the modification of zeolites with metal ions that form insoluble chromates or arsenates has been proposed for the removal of $\mathrm{Cr}$ and As (Section 2.1.3).

\subsubsection{Surfactant-modified zeolites (SMZ)}

One of the strategies for tailoring zeolites in order to allow adsorption of negatively charged species is the modification of the polarity of the surface using surfactant compounds. The surfactancy ability of zeolites is known from the 1980s, when zeolites replaced phosphates as water softeners in detergent formulations. The earliest reports of deliberate modification of the surface polarity of inorganic materials date back to 1988: Boyd et al. presented the modification of soil samples using the surfactant hexadecyltrimethylammonium (HDTMA), to allow the retention of several organic compounds [42].

Surfactant-modified zeolites (SMZ), also named organozeolites, are prepared using certain surfactant molecules, mostly quaternary amine salts, which can be ion-exchanged on the surface of the zeolite. If these amines are provided with one long alkyl chain, the hydrophilic section or "head" (where the positively charged nitrogen atom is located) will be attracted by the zeolite, whereas its hydrophobic counterpart (the alkyl "tail") will oppose the zeolite (Fig. 1). If the surfactant concentration in solution is kept below the respective critical micelle concentration $(\mathrm{cmc})$, a monolayer (hemimicelle) will form on the zeolite surface. If the 


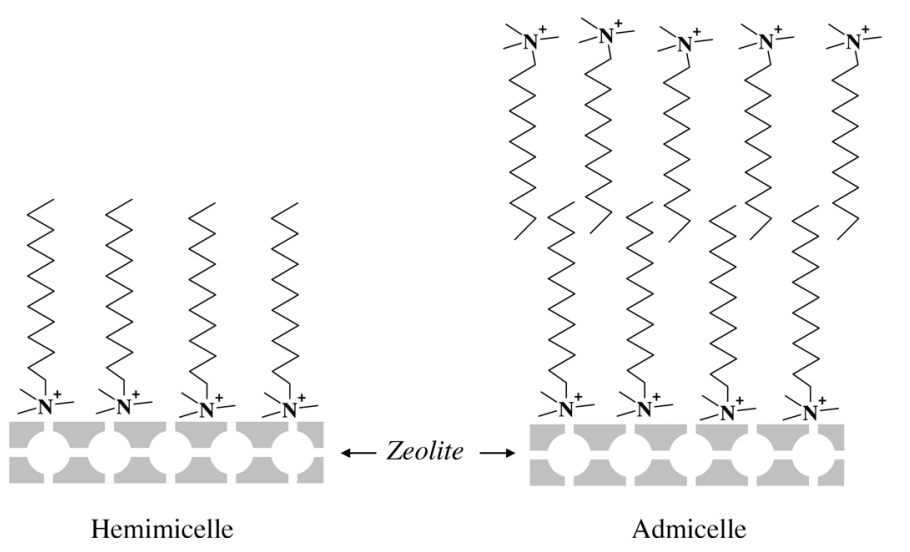

Fig. 1. Formation of a monolayer or double-layer on the zeolite surface by an alkylquaternary ammonium surfactant.

concentration of surfactant is further increased beyond $\mathrm{cmc}$, the hydrophobic tails will attract each other and form a double layer or admicelle [43] over the zeolite surface. This double layer will cover the zeolite with one of the $\mathrm{N}^{+} \mathrm{R}$ surfaces deposited on the zeolite and the other $\mathrm{N}^{+} \mathrm{R}$ surface facing the solution, therefore endowing the outer surface with positive charges. These can be used to adsorb metal oxyanions or other anions, as depicted in Fig. 2.

The $\mathrm{Cr}(\mathrm{VI})$ adsorption capacity of most surfactants used in the preparation of SMZs has been demonstrated even on the unsupported form (micelle form) [44]. While this fact may lead to consider this procedure as a more economical process when compared to the process costs of tailoring zeolites, Bowman described SMZs prepared from natural zeolites to be a cost-effective support [45], since natural zeolites are considerably less expensive than the cost of the surfactants used. Moreover, the same author added that SMZs have the potential of being alternative supports to activated carbon or ion-exchange resins. The advantages of being a heterogeneous support (granting ease in recovery) and still having the intrinsic properties of zeolites render SMZs attractive sorbents, especially for multi-component effluents. Zeolites present internal and external cation exchange sites; surfactant molecules exchange mainly in the outer layer sites, as their dimensions limit accessibility to the inner zeolite framework [46]. This allows zeolite to maintain their characteristic cation exchange ability after modification with surfactants, potentially allowing simultaneous retention of anionic species on the modified surface and cationic metal species on internal exchange sites. SMZs have also been found to be resistant to organic solvents, extreme $\mathrm{pH}$ conditions or high ionic strength [47], so their application range in liquid phase conditions is not restricted when compared to unmodified zeolites. Several surfactants have been successfully used to date, for the modification of either natural or synthetic zeolites, as well as other mineral

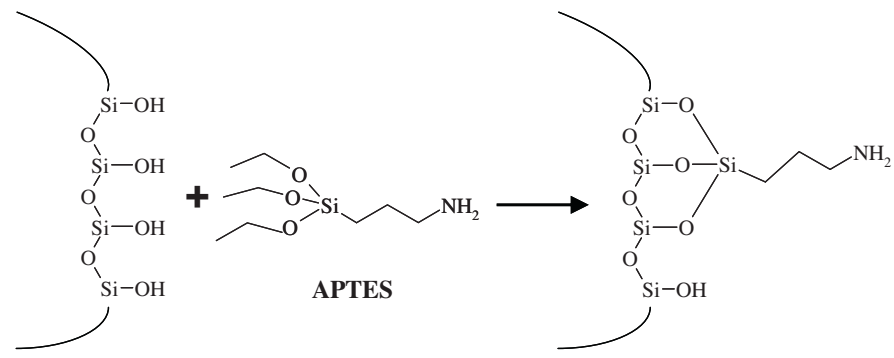

Fig. 3. Grafting of APTES into a silica-like surface.

compounds such as clays. This process enables not only the adsorption of metal oxyanions; sulfate, nitrate and phosphate $[48,49]$, organic and aromatic compounds [45,50], pharmaceutical drugs [51], bacteria [52] or even viruses [53] have been reported to be adsorbed on SMZs.

\subsubsection{Surface functionalization of zeolites}

An alternative route to modify zeolites in order to induce affinity for anions is surface functionalization. This can be achieved by grafting species with adequate anion-affinity on the surface of the zeolite, in a process that resembles to SMZ, as the objective is the inversion of the zeta potential of the surface of zeolites. However, some differences exist between surface functionalization and SMZ. While SMZs are prepared by adsorption of surfactants, grafting involves generation of covalent bonding between the grafting agent and the zeolite.

The most common grafting agents used are hybrid organic-inorganic compounds, such as alkyl silanes. These will bond to the zeolite surface silanol groups ( $\mathrm{SiOH})$, which are relatively reactive [54]. A review from Moller and Bain offered considerable detail on the silane-based functionalization of several MCM materials, as well as the respective reactive conditions for their preparation [55]. Fig. 3 illustrates an example of grafting aminopropyl-triethoxy-silane (APTES) into a silica-like surface. The amino group in APTES is useful for the adsorption of anions, as it is easily protonated through $\mathrm{pH}$ control [56,57], and therefore becomes able to retain negatively charged ions (Fig. 4).

Since $\mathrm{SiOH}$ groups are widely available in ordered silica-like structures, these are the predominant targets for surface functionalization. These groups are also available in Si-rich zeolites or Al-free zeolites (such as the silicallite MFI zeolite [58]), so surface functionalization of high $\mathrm{Si} / \mathrm{Al}$ ratio zeolites can result in high loading of organic matter on the support. Conversely, Alrich zeolites will be less prone to grafting silanes, since with the increase in $\mathrm{Al}$ content of a zeolite, the lesser available silanol groups will be present at the surface. Nevertheless, their higher capacity for cation exchange renders Al-rich more adequate supports for SMZ preparation. In this regard, surface functionalization and

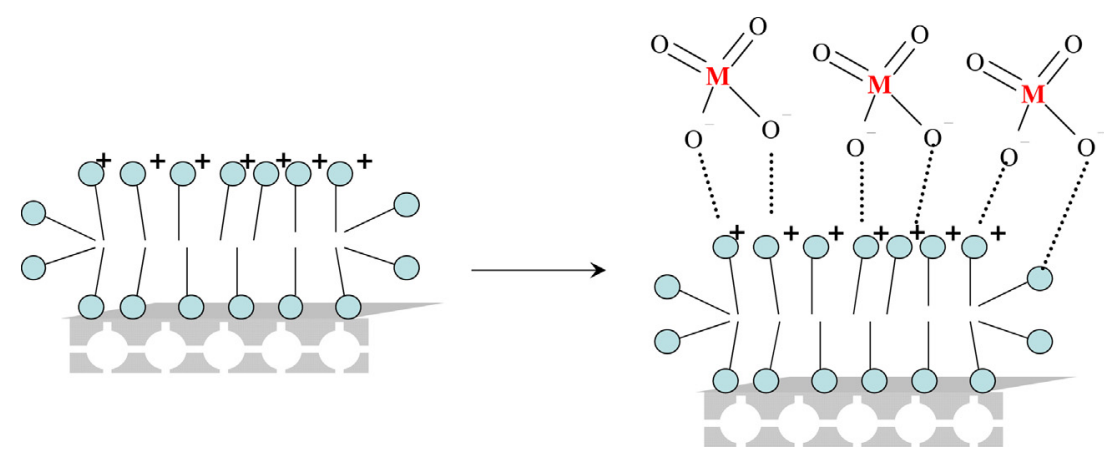

Fig. 2. Adsorption of a metal oxyanion on a SMZ. 


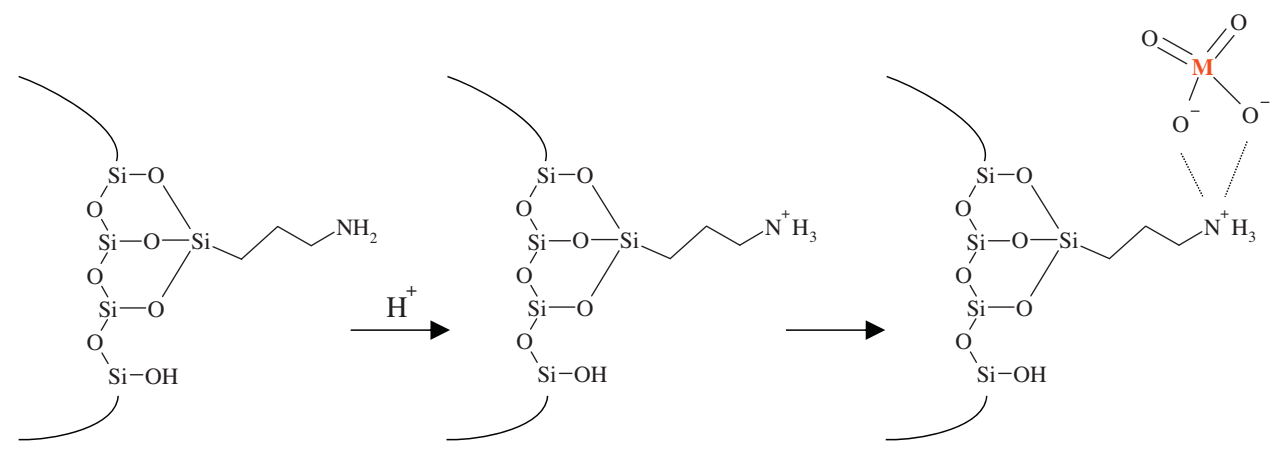

Fig. 4. Retention of a metal oxyanion by previously protonated amino-functionalized silica.

surfactant modification of zeolites can be considered two complementary techniques to induce changes on the zeta potential of zeolites according to the $\mathrm{Si} / \mathrm{Al}$ ratio.

Unlike most large pore mesoporous silica materials, zeolites present two types of available surface area: the internal surface area, only accessible to molecules that are able to diffuse through zeolite pores; and the external surface area [59]. The internal surface area is less prone to functionalization, as it presents less silanol groups as the external surface, being the hydroxyl groups available as the $\mathrm{Si}-(\mathrm{OH})-\mathrm{Al}$ acid Brønsted sites [60]. Therefore, zeolites are mainly functionalized on the outer surface area. Nano-crystalline zeolites have been considered more adequate supports for functionalization, as the ratio between external/internal surface area is higher [61].

As it is the case of SMZs, zeolites are able to maintain their intrinsic properties such as ion-exchange and shape selectivity after functionalization, which in turn allows for bi- or multi-functionality of these materials. This property is commonly explored in catalysis [59]; however, a different kind of bifunctional zeolites has been proposed by Barquist and Larsen for the specific removal of hexavalent chromium [62]. The authors selected magnetic Y zeolites as supports for the functionalization with APTES. The magnetization of $\mathrm{Y}$ zeolite can be achieved by forming iron oxides in the zeolite, through ion-exchange of $\mathrm{Fe}(\mathrm{III})$ and $\mathrm{Fe}(\mathrm{II})$ ions and then subjecting to alkaline treatment [63]. This property was chosen to overcome the hydrophobicity of APTES-functionalized zeolites, which tend to form colloidal suspensions in water media, therefore losing easiness of recovery.

\subsubsection{Metal modification of zeolites (MMZ)}

Anion adsorption on metal-modified zeolites has been studied for some time and the adsorption of $\mathrm{Cr}$ or As oxyanions has been successfully achieved.

Metal modification of zeolites can be performed by two processes: simple ion-exchange, using cationic metal ions that present great affinity for the target oxyanions; or through promoting the formation of metal oxide species on the zeolite. While the later allows direct adsorption and further retrieval of sorbates, the first method is usually employed to introduce oxyanion-precipitating agents or oxidant/reductant species in the zeolite that will perform the treatment of As or $\mathrm{Cr}$ oxyanions. In this section, only the processes for oxyanion removal without redox reactions will be detailed, while MMZs with reducing/oxidizing-species will be discussed later.

Zeolites most commonly present counter-ions from alkali or alkaline earth metal elements. The replacement of these for metals which form insoluble $\mathrm{Cr}$ and/or As salts has been proposed as a process for the removal of $\mathrm{Cr}(\mathrm{VI})$ and $\mathrm{As}(\mathrm{V})$ from solution. Chromate/dichromate and arsenate salts of metal ions such as $\operatorname{Ag}(\mathrm{I})$, $\mathrm{Al}(\mathrm{III}), \mathrm{Ba}(\mathrm{II}), \mathrm{Fe}(\mathrm{II})$ or $\mathrm{Fe}(\mathrm{III}), \mathrm{Hg}(\mathrm{II}), \mathrm{Pb}(\mathrm{II})$ and $\mathrm{Zn}(\mathrm{II})$ are highly insoluble, so provided zeolites are exchanged with these cations previously, it is possible to immobilize the corresponding chromates/arsenates on the zeolite. The preparation of this kind of MMZs is straightforward. Normally, the zeolite is impregnated with a solution of a salt of the selected metal ion, usually a nitrate or chloride. The solution is stirred at room temperature and the solid is recovered, washed and dried prior to application.

Ion-exchanged MMZs have demonstrated good performance, despite some detrimental re-solubilization of chromates and arsenates taking place. In order to overcome this limitation, covalently bonded metal oxide MMZs were successfully used for metal oxyanion removal. Iron oxides are commonplace for the preparation of metal oxide MMZs for arsenic removal. This is mainly due to the high success of granular ferric hydroxide (GFH) on the treatment of arsenic contamination [64], where the coupling of Fe oxides to zeolites attempts to mimic the specificity of GFH for arsenate-like ions. The preparation of Fe-MMZs normally adds a calcination step following the ion-exchange procedure, where the sample is calcined in alternating oxidizing/reducing atmospheres (ex: $\mathrm{N}_{2}$ and $\mathrm{H}_{2}$ ) [65]. This class of materials is often termed iron-coated zeolites (ICZ).

The formation of other metal oxides on zeolites bears a similar principle to the previously described, where the zeolite is impregnated with the chosen metal, followed by slow addition of a base, normally $\mathrm{NaOH}$, to promote the formation of metal oxides on the zeolite upon drying or calcination [66]. This process was also successfully used for the preparation of magnetic zeolites, using a mixture of $\mathrm{Fe}(\mathrm{II}) / \mathrm{Fe}(\mathrm{III})$ ions $[63,67]$. The adsorption of $\mathrm{Cr}$ and $\mathrm{As}$ in metal-oxide MMZs is reversible, offering an easier recovery of the removed compounds, when compared the other MMZs.

\subsection{Zeolite conjugation with reducing/oxidizing species}

A different perspective for the removal of metal oxyanions with zeolites is to convert them through redox reactions into other ions which are possible to be exchanged by the zeolite.

This is mostly evident for $\mathrm{Cr}(\mathrm{VI})$. Both natural and synthetic zeolites possess limited affinity for hexavalent chromium, but have demonstrated good ion-exchange properties for the trivalent form. This occurs since $\mathrm{Cr}(\mathrm{III})$ forms cationic species in aqueous solution. Therefore, provided that $\mathrm{Cr}(\mathrm{VI})$ is previously reduced to $\mathrm{Cr}(\mathrm{III})$, zeolites would then be able to recover $\mathrm{Cr}$ from solution in an indirect process. Overall, the reduction of hexavalent chromium occurs according to Eq. (1) (for acidic pH) or Eq. (2) (for alkaline pH) [22]:

$\mathrm{Cr}_{2} \mathrm{O}_{7}{ }^{2-}+14 \mathrm{H}^{+}+6 \mathrm{e}^{-} \rightarrow 2 \mathrm{Cr}^{3+}+7 \mathrm{H}_{2} \mathrm{O} \quad \mathrm{E}^{\circ}=+1.33 \mathrm{eV}$

$\mathrm{CrO}_{4}^{2-}+4 \mathrm{H}_{2} \mathrm{O}+3 \mathrm{e}^{-} \rightarrow \mathrm{Cr}(\mathrm{OH})^{3+}+5 \mathrm{OH}^{-} \quad \mathrm{E}^{\circ}=-0.12 \mathrm{eV}$ 
The inversion of charge in arsenic ions is not so straightforward as between $\mathrm{Cr}(\mathrm{VI}) / \mathrm{Cr}(\mathrm{III})$. Both $\mathrm{As}(\mathrm{V})$ and $\mathrm{As}(\mathrm{III})$ exist in nature as oxyanions, being the redox properties of the $\mathrm{As}(\mathrm{V}) / \mathrm{As}(\mathrm{III})$ pair described in Eq. (3) [68]. Despite that the redox pair As(III)/As(V) does not yield any cationic species, the oxidation of arsenite to arsenate is still of great importance since the trivalent form is more toxic and more difficult to remove.

$\mathrm{H}_{3} \mathrm{AsO}_{4}+2 \mathrm{H}^{+}+2 \mathrm{e}^{-} \rightarrow \mathrm{H}_{3} \mathrm{AsO}_{3}+\mathrm{H}_{2} \mathrm{O} \quad \mathrm{E}^{\circ}=+0.56 \mathrm{eV}$

Different redox-assisted processes for the treatment of $\mathrm{Cr}$ and As on modified zeolites have been mentioned in the literature. All consist in endowing the zeolite with redox agents that assist the retention by the system. MMZs have also been proposed for the redox-assisted removal of oxyanions, or as photocatalysts for the treatment of the same. These will be detailed in Sections 2.2.1 and 2.2.2 respectively. Other option is the combination of biomass with zeolites (Section 2.2.3).

\subsubsection{Metal-modified zeolites for redox processes}

MMZs have also been successfully used in redox processes for the treatment of $\mathrm{Cr}$ and As. The previously described methods for the preparation or MMZs are also valid for the incorporation of reducing/oxidizing particles. Iron is commonly found coupled to zeolites for redox processes of $\mathrm{Cr}(\mathrm{VI})$ or As (III), with iron species such as $\mathrm{Fe}(\mathrm{III}), \mathrm{Fe}(\mathrm{II})$ and zerovalent iron. For the particular case of the conversion of arsenite to arsenate, $\mathrm{Fe}(\mathrm{III})$ is commonly employed to assist the oxidation, since the formal electrode potential of the $\mathrm{Fe}(\mathrm{III}) / \mathrm{Fe}(\mathrm{II})$ pair is higher than for $\mathrm{As}(\mathrm{V}) / \mathrm{As}(\mathrm{III})$ [68]. For the $\mathrm{Cr}(\mathrm{VI}) / \mathrm{Cr}(\mathrm{III})$ system, $\mathrm{Fe}(\mathrm{II})$ salts are used as the reductant in the reduction-precipitation process, which is the common industrial treatment procedure for hexavalent $\mathrm{Cr}$ [69]. Apart from iron, manganese species were also successfully combined with zeolites for the oxidation and removal of As(III) [70].

\subsubsection{Photocatalytic processes}

Photocatalysis arises from the generation of electron-hole pairs on a semiconductor material through photon absorption, leading to chemical reactions between the semiconductor surface and molecules in the vicinity [69]. Photocatalysis has been successfully applied to the treatment of $\mathrm{Cr}$ and As solutions, by promoting either reduction of $\mathrm{Cr}(\mathrm{VI})$ to $\mathrm{Cr}(\mathrm{III})$, or oxidation of $\mathrm{As}(\mathrm{III})$ to $\mathrm{As}(\mathrm{V})$. To this effect, prominent heterogeneous photocatalysts such as $\mathrm{TiO}_{2}$ and $\mathrm{ZnO}$ have been successfully used [71].

Zeolite-based photocatalysts have found application in advanced oxidation processes. Despite these advances, only a limited number of papers detail the use of zeolite photocatalysts for the purpose of $\mathrm{Cr}(\mathrm{VI})$ treatment, albeit some interest in mesoporous silica is reported.

To the best of our knowledge, no photocatalytic process has been reported for As(III) oxidation and removal using zeolite-supported photocatalysts. This particular reaction has long been reported using suspended $\mathrm{TiO}_{2}$ photocatalyst, and reports of successful application of $\mathrm{TiO}_{2}$ supported in activated carbon or activated alumina have also been presented [71]. Hence, the perspective of zeolites as useful supports could be also considered for the case of arsenic.

\subsubsection{Zeolites as supports for bioremediation of $\mathrm{Cr}$ and As oxyanions}

Biosorption of metal contaminants has been thoroughly investigated and is a cost-effective and environmental alternative to less efficient metal treatment processes [2,72,73]. Different kinds of biomass, either live or dead, are able to retain metal ions on the high multiplexity of chemical groups present on cellular structures. Bacteria are well known for their use on the treatment of metal contaminated solutions [2]. The structural polymers on bacterial cell walls present several functional groups such as carboxyl, phosphoryl and amino groups, which are directly responsible for the reactivity of bacterial cells to aggression from metal contaminants [74]. The external surface of bacteria is intrinsically reactive toward dissolved metals, despite the different surface formats between the different types of bacteria.

While the removal and recovery of most metal cations through biosorption has been demonstrated, mechanisms regarding the biosorption of $\mathrm{Cr}(\mathrm{VI})$ and $\mathrm{As}(\mathrm{III}) /(\mathrm{V})$ by live bacteria present interesting differences. Bacteria are able to reduce $\mathrm{Cr}(\mathrm{VI})$, owing to the high electronic density on the cell surface. Several microorganisms have been used for the removal of chromium from effluents with very promising results [75-79]. The mechanism of $\mathrm{Cr}(\mathrm{VI})$ bioreduction was intensively studied by Park et al., who provided evidence that the process is an "adsorption-coupled-reduction" $[80,81]$. Many functional groups that are present on cell walls can act as electron donors [82] and the diol-rich polysaccharide content of cell walls was found to coordinate with an intermediary oxidation state, $\mathrm{Cr}(\mathrm{V})$, hence assisting the overall reduction process. This unstable intermediary was found to be present on Cr-reducing cells [26]. In terms of bacterial oxidation of As(III), despite being inhibitory to cellular growth, some bacteria are able to use the redox pair $\mathrm{As}(\mathrm{III}) / \mathrm{As}(\mathrm{V})$ in the electron transport during the respiratory cycle. Specific arsenic-reducing or -oxidizing enzymes have been extracted from bacteria and the $\mathrm{As}(\mathrm{V})$ and $\mathrm{As}(\mathrm{III})$ uptake and cellular pathways have been reported $[31,83,84]$. Under the scope of As contamination treatment, As(III)-oxidizing bacteria can play a helpful role on the preconcentration of the easier to recover $\mathrm{As}(\mathrm{V})$ ions.

The combination of biosorbents with a zeolitic support offers some advantages. Solely suspended microorganisms present the disadvantages of being too sensitive to the xenobiotic effects caused by high levels of pollutant concentration. Also, mechanical strength and low density of microorganisms in suspension can hinder the performance of treatment systems [85]. Immobilization of biomass on a support offers the advantages of mechanical resistance and higher packing capacity. To this respect, zeolites and minerals provide a resistant support that can actively take part on the removal of the metal that underwent the redox process, promoted by the supported biomass.

\section{Results and achievements on oxyanion removal with tailored zeolites}

This section presents an overview on how the previously described zeolite tailoring strategies perform on the removal of arsenic and chromium oxyanions. While the treatment of $\mathrm{Cr}(\mathrm{VI})$ has been the driving force for the development of most processes, given the lesser natural affinity of zeolites for this case, some were also successfully applied to arsenic remediation as well. It is common to see studies including other oxyanions as well, and in fact, some works present the simultaneous treatment of As and $\mathrm{Cr}$ oxyanions with tailored zeolites [7,86,87]. Additionally, some of the tailoring strategies can be combined, as it is the case of MMZs which are also modified with surfactants [88,89]. The efficiency of the different approaches will be presented according to the respective processes and technologies detailed in Section 2. $\mathrm{Cr}$ and As uptake values are merely presented for illustration purpose, and should not be considered for a performance comparison between tailoring strategies, or even between results obtained for the same zeolite modification. Operational conditions between cited works are not identical and key parameters, such as initial oxyanion concentration, $\mathrm{pH}$ and contact time, are only mentioned in the text where appropriate. Additionally, the presented maximum uptake values 
refer to either experimentally observed, or as predicted from the Langmuir adsorption model, at equilibrium state.

Despite having covered the different zeolite tailoring strategies for oxyanions in the previous section, it is worth to note that the removal of oxyanions using unmodified natural or synthetic zeolites has also been reported. This is commonly reported for the removal of arsenate ions, and the highly chemically related phosphate and antimonate oxyanions have also been found to adsorb on natural zeolites $[33,90,91]$. The general principle ruling zeolite affinity for this compound family is thought to involve the properties of the surface aluminol groups which, at specific $\mathrm{pH}$ values, promote the formation of surface inner-sphere complexes with these compounds [91-93]. At very low $\mathrm{pH}$ values, below the point of zero charge ( $p z c$ ) of most zeolites, aluminol groups are protonated (Eq. (4)), while above pzc, they can be deprotonated by hydroxyl ions. Ions such as arsenate and phosphate react with either protonated or neutral aluminol groups, depending on solution $\mathrm{pH}$ being below or at near pzc (Eqs. (5) and (6)) [91,94].

Zeolite-AlOH $+\mathrm{H}_{3} \mathrm{O}^{+} \leftrightarrow$ Zeolite- $\mathrm{Al}\left(\mathrm{OH}_{2}\right)^{+}+\mathrm{H}_{2} \mathrm{O}$

Zeolite-Al $\left(\mathrm{OH}_{2}\right)^{+}+\mathrm{H}_{2} \mathrm{XO}_{4}{ }^{-} \leftrightarrow$ Zeolite-AlO- $\left(\mathrm{XO}(\mathrm{OH})_{2}\right)+\mathrm{H}_{2} \mathrm{O}$

$$
\mathrm{X}=\text { AsorP }
$$

Zeolite-AlOH $+\mathrm{H}_{2} \mathrm{XO}_{4}{ }^{-} \leftrightarrow$ Zeolite-AlO- $\left(\mathrm{XO}(\mathrm{OH})_{2}\right)+\mathrm{OH}^{-}$

$$
\mathrm{X}=\text { AsorP }
$$

Some authors also defend that the retention of $\mathrm{As}(\mathrm{V})$ by natural zeolites is assisted by their composition presenting a diversity of charge-balancing cations, some of which residual amounts of transition metal cations presenting affinity for $\mathrm{As}(\mathrm{V})$ in the same perspective as a metal-modified zeolite would perform. Residual iron and manganese ions in the composition of natural zeolites are regarded as useful on both retention of $\mathrm{As}(\mathrm{V})$ or oxidation of $\mathrm{As}(\mathrm{III})$ [95].

Despite the affinity between arsenic compounds and zeolites, some authors still conduct modification of zeolites for the improvement of specific properties, such as hydrophobicity and mechanical resistance (in SMZs), for promoting oxidation of $\mathrm{As}(\mathrm{III})$ to $\mathrm{As}(\mathrm{VI})$ or to induce multifunctionality. As an example, SMZs offer the possibility of retaining both arsenic and other oxyanions such as chromate [86], while not compromising the zeolite ability to retain As $(V)$. This was demonstrated by Chutia et al., whom published two simultaneous reports on the removal of arsenic, one describing the use of unmodified synthetic H-MFI zeolites and the other, the use of surfactant-modified natural zeolites. The authors observed that both systems were able to remove $\mathrm{As}(\mathrm{V})$ and regeneration of the supports was possible, through washing with $\mathrm{NaOH}$ or $\mathrm{HCl}[94,96]$.

\subsection{Direct adsorption of $\mathrm{Cr}(\mathrm{VI})$ and $A s(V) / A s(I I I)$}

\subsubsection{Use of SMZs for the removal of $C r(V I)$ and As oxyanions}

The earliest application of SMZs for the removal of $\mathrm{Cr}(\mathrm{VI})$ can be traced back to a report by Santiago et al. in 1992 [4], with the use of ethylhexadecyldimethylammonium (EHDDMA) and cetylpyridinium (CPD) to modify the zeolite surface. The authors found the CPD-SMZ support more efficient for chromate removal, with an uptake of $0.65 \mathrm{mg}_{\mathrm{Cr}} / \mathrm{g}_{\text {zeolite }}$. Arsenic removal using both natural and surfactant-modified zeolites was reported later, in 1997 for the removal with unmodified zeolites, while a year later, Misaelides et al. described the earliest application of SMZs from natural zeolites for the removal of $\mathrm{As}(\mathrm{V})[95,97]$.
Soon after the initial studies of $\mathrm{Cr}(\mathrm{VI})$ removal by SMZs, Haggerty and Bowman demonstrated that an adsorption process, where reduction of $\mathrm{Cr}(\mathrm{VI})$ does not occur, was the global mechanism for the removal of this oxyanion [43]. Also for $\mathrm{Cr}(\mathrm{VI})$, Covarrubias et al. further commented that for monolayer SMZs, the global process that takes place is a surface precipitation, while for surfactant bilayer SMZs, ion-exchange with the surfactant counter-ions is the main process involved [98]. Li et al. demonstrated that the release of counter-ion(s) to the solution is directly related to the amount of sorbed $\mathrm{Cr}(\mathrm{VI})$ on SMZ packed columns [99]. As further evidence of the adsorption mechanism, the removal of chromate from solution by SMZs is commonly reported to be well fitted by the Langmuir adsorption model. As an example, Ghiaci et al. performed a study on $\mathrm{Cr}(\mathrm{VI})$ removal by natural clinoptilolite, ZSM-5 zeolite and MCM41 molecular sieve, all tailored with HDTMA and CPD surfactants. Both the adsorption of the surfactants by the zeolites and the following adsorption of chromate by the SMZs were well fitted by the Langmuir adsorption model [100].

In terms of recovery-reuse procedures for SMZs, several authors reported the possibility for regeneration of the prepared supports. A recent report by Zeng et al. demonstrated the reusability of their HDTMA-surfacted clinoptilolite and chabazite supports [101]. The regeneration of the SMZs was conducted by rinsing the support with $0.1 \mathrm{M} \mathrm{HCl}$, and the regenerated support was able to achieve $90.6 \%$ of the $\mathrm{Cr}(\mathrm{VI})$ removal of as-prepared equivalent SMZ. The same principle is valid for $\mathrm{As}(\mathrm{V})$ sorption and desorption with natural zeolite SMZs, as previously referred from the works of Chutia et al. [96]. In the latest, the authors employed $\mathrm{NaOH}$ or $\mathrm{HCl}$ at a concentration of $0.1 \mathrm{M}$, with the alkaline washing achieving greater recovery of the sorbed $\mathrm{As}(\mathrm{V})$ ions, at 70\% desorption efficiency vs. less than $50 \%$ for $\mathrm{HCl}$.

Table 1 presents an overlook on the achievements of different SMZs in the adsorption of $\mathrm{Cr}(\mathrm{VI})$ or $\mathrm{As}(\mathrm{V})$. The predominance of works using natural zeolites is noteworthy, which reflects authors' efforts to address both cost-effective and environmental concerns. Nevertheless, SMZs prepared from synthetic zeolites have also been successfully employed on the removal of $\mathrm{Cr}(\mathrm{VI})$ and $\mathrm{As}(\mathrm{V})$.

A variation from the previous SMZs was recently reported by Shyaa, Hasan and Abbad. The authors proposed a polyanilineloaded zeolite nanocomposite for the removal of $\mathrm{Cr}(\mathrm{VI})$. The modification of the zeolite was conducted though adsorption of anilinium ions on the zeolite inner and outer surface, being these ions latter polymerized with ammonium persulphate [111]. The system was able to achieve a maximum uptake of $25 \mathrm{mg} \mathrm{gr}_{\mathrm{r}} / \mathrm{g}_{\text {zeolite }}$, from an initial solution of $100 \mathrm{mg}_{\mathrm{Cr}} / \mathrm{L}$.

\subsubsection{Functionalized zeolites}

To date, the most studied organic-functionalized materials have been mesoporous, high-Si content supports [112]. The application of functionalized silica to the selective removal of oxyanions has been proposed since the late 1990s, with the work of Fryxell et al. on the usage of mesoporous silica functionalized with ethylenediamine silane, that was later reacted with $\mathrm{Cu}(\mathrm{II})$ ions, resulting in a selective adsorbent for $\mathrm{As}(\mathrm{V})$ and $\mathrm{Cr}(\mathrm{VI})$ in presence of other competing anions [113]. The basic principle is to immobilize coordinated $\mathrm{Cu}(\mathrm{II})$ species which are positively charged and possess electrosteric coordination affinity for tetrahedral anions, such as chromate. The authors reported a maximum uptake of $54 \mathrm{mg}_{\mathrm{Cr}} / \mathrm{g}_{\text {support }}$ from initial concentrations ranging to $1000 \mathrm{mg}_{\mathrm{Cr}} / \mathrm{L}$. Also, chromium sorption was not significantly disturbed by competing sulfate anions present at $150 \mathrm{mg} / \mathrm{L}$. Later, Yukoi et al. studied the functionalization of MCM-41 with coordinated $\mathrm{Fe}(\mathrm{III})$ as a selective adsorbent for $\mathrm{Cr}(\mathrm{VI}), \mathrm{As}(\mathrm{V}), \mathrm{Mo}(\mathrm{VI})$ and $\mathrm{Se}(\mathrm{VI})$ [114]. The authors reported a maximum uptake of $95 \mathrm{mg}_{\mathrm{Cr}} / \mathrm{g}_{\text {support }}$ for an initial concentration of $230 \mathrm{mg}_{\mathrm{Cr}} / \mathrm{L}$. Yoshitake et al. used mono-, diand tri-amino substituted MCM-41 and SBA-1 mesoporous silica to 
Table 1

Overview of different SMZs and uptake capacities for $\mathrm{Cr}(\mathrm{VI})$ and $\mathrm{As}(\mathrm{III}) / \mathrm{As}(\mathrm{V})$.

\begin{tabular}{|c|c|c|c|c|}
\hline \multirow[t]{2}{*}{ Selected zeolite } & \multirow[t]{2}{*}{ Selected surfactant } & \multicolumn{2}{|c|}{ Maximum uptake observed ( $\left.\mathrm{mg} / \mathrm{g}_{\text {support }}\right)$} & \multirow[t]{2}{*}{ Reference(s) } \\
\hline & & $\mathrm{Cr}(\mathrm{VI})$ & $\mathrm{As}(\mathrm{III})$ or $\mathrm{As}(\mathrm{V})$ & \\
\hline \multirow[t]{4}{*}{ Natural clinoptilolite } & HDTMA & 13.22 & 3.7 & {$[43,49,96,99-105]$} \\
\hline & $\mathrm{CPB}$ & 3.5 & & {$[100,106]$} \\
\hline & PHMG & 3.0 & 6.73 & {$[97,107]$} \\
\hline & ODTMA & 2.3 & & [9] \\
\hline \multirow[t]{3}{*}{ Natural mordenite } & HDTMA & 0.023 & 4.6 & {$[96,108]$} \\
\hline & EHDDMA & 0.017 & & {$[108]$} \\
\hline & $\mathrm{CPB}$ & 6.9 & & [98] \\
\hline \multirow[t]{2}{*}{ Natural chabazite } & $\mathrm{CPB}$ & 14.0 & & {$[106]$} \\
\hline & HDTMA & 8.83 & & {$[101]$} \\
\hline \multirow{2}{*}{ Natural laumontite-stilbite conjugate } & HDTMA & & 0.71 & [109] \\
\hline & EHDDMA & & 0.57 & \\
\hline Natural natrolite & HMNA & 2.3 & & {$[110]$} \\
\hline Synthetic LTA & HDTMA & 1.2 & 1.3 & [87] \\
\hline \multirow[t]{2}{*}{ Synthetic FAU type } & HDTMA & 2.0 & 1.4 & [7] \\
\hline & $\mathrm{CPB}$ & 8.0 & & [98] \\
\hline Synthetic LTA type & $\mathrm{CPB}$ & 6.0 & & [98] \\
\hline \multirow[t]{2}{*}{ ZSM-5 (MFI) } & HDTMA & 0.66 & & [100] \\
\hline & $\mathrm{CPB}$ & 0.53 & & \\
\hline
\end{tabular}

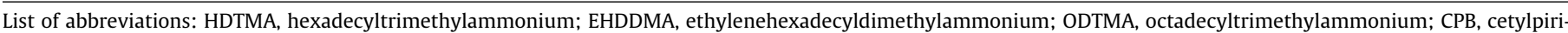
dinium bromide; PHMG, polyhexamethyleneguanidine, HMNA, hexamethyl-1,9-nonanediammonium.

remove chromate and arsenate [86]. The triamino-SBA-1 support achieved the highest uptake of chromate $\left(28 \mathrm{mg}_{\mathrm{Cr}} / \mathrm{g}_{\text {support }}\right.$, from a $317 \mathrm{mg}_{\mathrm{Cr}} / \mathrm{L}$ solution). Lam et al. obtained $-\mathrm{NH}_{2}$ and $-\mathrm{COO}^{-} \mathrm{Na}^{+}$ functionalized MCM-41 supports for the selective separation of dichromate and $\mathrm{Cu}(\mathrm{II})$ ions [57]. Once protonated at $\mathrm{pH} 2, \mathrm{NH}_{2}-$ MCM-41 was able to completely separate dichromate ions from $\mathrm{Cu}(\mathrm{II})$, achieving an uptake of $23 \mathrm{mg}_{\mathrm{Cr}} / \mathrm{g}_{\text {support }}$ (initial $\mathrm{Cr}(\mathrm{VI})$ concentration was $7 \mathrm{mg} / \mathrm{L}$ ).

As previously mentioned APTES-functionalized zeolites present hydrophobicity and tend to form colloidal suspensions in aqueous media, hence losing easiness of recovery. To overcome this limitation, Barquist and Larsen proposed the added magnetization of a APTES-modified Y zeolite for the specific removal of $\mathrm{Cr}(\mathrm{VI})$ [62]. The authors proposed the ion-exchange of $\mathrm{Fe}(\mathrm{III})$ and $\mathrm{Fe}(\mathrm{II})$ ions followed by alkaline treatment in order to promote the formation of iron oxides. The functionalized supports were able to remove $\mathrm{Cr}(\mathrm{VI})$ up to $44 \mathrm{mg}_{\mathrm{Cr}} / \mathrm{g}_{\text {support }}$ (being the maximum initial $\mathrm{Cr}$ concentration of $2 \mathrm{mM}$ ) and the magnetization of the zeolite was attained. A different approach was presented by Chen et al. [115], with the preparation of magnetic siliceous MCM- 41 for the selective removal of arsenic and chromium from solution. For the magnetization of the support, magnetic iron oxide nanoparticles $\left(\mathrm{Fe}_{3} \mathrm{O}_{4}\right)$ were added to the reaction mixture for the synthesis of MCM41 , and the support presented magnetic properties straight after the synthesis. Subsequently, the support was functionalized with aminopropyltrimethoxysilane (APTMS) and exchanged with $\mathrm{Fe}^{3+}$ in order to acquire selectivity for oxyanions. The authors reported a maximum uptake of $91 \mathrm{mg}_{\mathrm{Cr}} / \mathrm{g}_{\text {support }}$ and chromate was selectively removed in the presence of $\mathrm{Cu}^{2+}$ ions. The comparison between the APTMS-magnetic MCM-41 and the APTMS-non-magnetic counterpart proved that the presence of the iron oxide nanoparticles did not interfere with the removal of chromate, as the uptakes were similar between the two supports. Moreover, recovery of the support with a magnet proved to be a much easier process than gravity sedimentation. While this support was able to achieve a higher uptake compared to the magnetic NaY support of Barquist and Larsen, it should be pointed that $\mathrm{Y}$ zeolite has a higher amount of $\mathrm{Al}$ in its composition, which decreases the capacity for functionalization (authors reported a $\mathrm{Si} / \mathrm{Al}$ ratio of 2 ); also, the magnetization of the support was conducted post-synthesis and the magnetic iron oxides were formed in situ.

\subsubsection{Metal modified zeolites}

The application of MMZs in arsenic and chromium oxyanions removal is a rather recent effort. While SMZs gained notoriety in the 1980s, MMZs were only applied in this field at the start of the XXIst century. The main obstacle for direct adsorption with MMZs is the efficiency of the retention of arsenate or chromate on the zeolite. This was very well illustrated in one of the early publications in the field, from Faghihian and Bowman. It was interesting as these authors have a strong background in chromate removal with SMZ and investigated the potential of MMZs from natural clinoptilolite, exchanged with several mono-, di- and trivalent cations as inducers of surface precipitation of the corresponding insoluble chromates [116]. A correlation was found between the solubility product of the different chromates and the corresponding chromate uptake by the different MMZs. The maximum uptake was achieved with the Pb-loaded sample, which forms the least soluble chromate from the ions in study, at $29 \mathrm{mg}_{\mathrm{Cr}} / \mathrm{g}_{\text {zeolite }}$. This was sequentially followed by the samples loaded with $\mathrm{Ag}^{+}\left(21 \mathrm{mg}_{\mathrm{Cr}} / \mathrm{g}_{\text {zeolite }}\right), \mathrm{Hg}^{2+}$ $\left(19 \mathrm{mg}_{\mathrm{Cr}} / \mathrm{g}_{\text {zeolite }}\right)$ and $\mathrm{Ba}^{2+}\left(18 \mathrm{mg}_{\mathrm{Cr}} / \mathrm{g}_{\text {zeolite }}\right)$. The authors concluded that the prepared MMZs allowed a much higher uptake of chromate than the comparatively obtained using SMZs. However, the authors also observed that, while very insoluble, minimal loss of the adsorbed lead or mercury chromates did occur, and the toxicity associated to these compounds render this approach undesirable for environmental remediation. A compromise between performance and environmental safety can be achieved when the less toxic barium ions are used in MMZs, and this was the choice of Bolortamir and Egashira in their study of Ba-exchanged natural zeolite, bearing mainly clinoptilolite and some mordenite phases [117]. The authors tested several zeolitic fractions with differing $\mathrm{Ba}^{2+}$ loading and achieved uptake figures ranging from 5 to $30 \mathrm{mg}_{\mathrm{Cr}} / \mathrm{g}_{\text {zeolite }}$.

For the removal of arsenic oxyanions, metal ions such as aluminum, iron and manganese found particular success in the formulation of MMZs. Xu, Okhi and Maeda proposed Al-exchanged natural zeolite (Shirazu zeolite) for the removal of arsenate $[118,119]$. Depending on $\mathrm{pH}$ and the arsenate/sorbent ratio, uptakes values of $6 \mathrm{mg}_{\text {As }} / \mathrm{g}_{\text {zeolite }}$ were achieved. Desorption of arsenate against $\mathrm{NaOH}$ was reported and the supports were re-used, showing some loss of arsenate removal performance (up to 30\% loss), which was found to be easily compensated by re-generating 
Table 2

Overview of different MMZs and uptake capacities for $\mathrm{Cr}(\mathrm{VI})$ and $\mathrm{As}(\mathrm{III}) / \mathrm{As}(\mathrm{V})$.

\begin{tabular}{|c|c|c|c|c|c|}
\hline \multirow[t]{2}{*}{ Modification } & \multirow[t]{2}{*}{ Selected zeolite } & \multirow[t]{2}{*}{ Metal modification compounds } & \multicolumn{2}{|c|}{ Maximum uptake observed (mg/g support $\left._{\text {sum }}\right)$} & \multirow[t]{2}{*}{ Reference(s) } \\
\hline & & & $\mathrm{Cr}(\mathrm{VI})$ & $\mathrm{As}(\mathrm{III})$ or $\mathrm{As}(\mathrm{V})$ & \\
\hline \multirow{15}{*}{ Ion exchange } & Nat. clinoptilolite & $\mathrm{Pb}(\mathrm{II})$ & 29 & & {$[116]$} \\
\hline & & $\operatorname{Ag}(\mathrm{I})$ & 21 & & \\
\hline & & $\mathrm{Hg}$ (II) & 19 & & \\
\hline & & $\mathrm{Ba}(\mathrm{II})$ & 18 & & \\
\hline & & $\mathrm{Ba}(\mathrm{II})$ & 30 & & {$[117]$} \\
\hline & & $\mathrm{Fe}(\mathrm{III})$ & & $0.024(\mathrm{As}(\mathrm{III}))$ & [121] \\
\hline & & & & $0.196(\mathrm{As}(\mathrm{V}))$ & \\
\hline & & $\mathrm{Fe}(\mathrm{III})$ & & 0.010 & {$[123,129]$} \\
\hline & & $\mathrm{Fe}(\mathrm{III}) / \mathrm{Mn}(\mathrm{II})$ & & 0.010 & \\
\hline & & $\operatorname{Mn}(\mathrm{II})$ & & 0.005 & \\
\hline & Shirazu zeolite & $\mathrm{Al}(\mathrm{III})$ & & 6 & {$[120]$} \\
\hline & Nat. chabazite & $\mathrm{Fe}(\mathrm{II})$ & & 0.070 & {$[122]$} \\
\hline & Nat. clinoptilolite & & & 0.035 & \\
\hline & Synt. FAU (13X) & & & 0.010 & \\
\hline & Synt. LTA (5A) & & & 0.065 & \\
\hline \multirow{7}{*}{ Metal oxide formation } & Nat. clinoptilolite & Fe oxide & 0.082 & & {$[124]$} \\
\hline & & & & 0.69 & {$[125]$} \\
\hline & & Fe oxide & & 3.87 & {$[66]$} \\
\hline & & Al oxide & & 2.14 & \\
\hline & & Fe and $\mathrm{Al}$ oxide & & 5.11 & \\
\hline & & Mn oxide & & 0.034 & [127] \\
\hline & Fly ash cancrinite & Al oxide & & 34.5 & [128] \\
\hline
\end{tabular}

the MMZ with fresh aluminum solution prior to a new arsenic removal cycle. The authors also tested the influence of competing anions such as phosphate, chromate, nitrate and others, and reported that only the chemically related phosphate ion had a significant interference in arsenate removal [120]. A recent publication by Šiljeg et al. reported an iron-modified natural clinoptilolite for the removal of $\mathrm{As}(\mathrm{III})$ and $\mathrm{As}(\mathrm{V})$ ions. The authors reported a detrimental influence of sulfate and phosphate ions on the overall efficiency, while desorption studies with $\mathrm{HCl}$ revealed that the retrieval of $\mathrm{As}(\mathrm{III})$ from the support was possible, but $\mathrm{As}(\mathrm{V})$ desorption was residual [121]. Previously, Payne and Abdel-Fattah reported that $\mathrm{Fe}(\mathrm{II})$-modified natural chabazite, clinoptilolite and synthetic faujasite and LTA zeolite were able to remove As(III) and $\mathrm{As}(\mathrm{V})$ [122]. The individual and combined performance of iron and/or manganese MMZs for arsenate removal was well illustrated in a publication from Jiménez-Cedillo et al. By exchanging $\mathrm{FeCl}_{3}$ and $\mathrm{MnCl}_{2}$ in natural Mexican clinotptilolite, the authors prepared Fe-, $\mathrm{Mn}$ - and Fe-Mn-MMZs which were used in the removal of arsenate in concentrations up to $0.1 \mathrm{ppm}$ [123]. Sorption equilibrium was quickly attained and the maximum uptake of $8 \mu \mathrm{g}_{\mathrm{As}(\mathrm{V})} / \mathrm{g}_{\text {zeolite }}$ was achieved with the Fe-MMZ sample with higher Fe(III) loading. For comparative metal loadings, it was found that the arsenate removal performance increased in the following sequence: MnMMZ, Mn-Fe-MMZ and Fe-MMZ.

In terms of application of metal oxide MMZs for oxyanion adsorption, the main focus between arsenic or chromium compounds appears to lie on the first. For the removal of chromate, the few publications available report the use of iron-coated zeolites (ICZ). Very recently, Du et al. reported the preparation of a ICZ from St. Cloud Mountain (USA) natural zeolite, which achieved a maximum uptake of $82 \mu \mathrm{g}_{\mathrm{Cr}} / \mathrm{g}_{\text {zeolite }}$ from batch studies (initial $\mathrm{Cr}$ concentration of $50 \mathrm{mg} / \mathrm{L}$ maximum) [124]. Arsenic has received a slightly wider array of MMZs. An example of $\mathrm{As}(\mathrm{V})$ removal with natural clinoptilolite ICZ was reported by Jeon et al., whom also studied the effect of competing sulfate ions on the arsenic removal efficiency [125]. Starting from diluted $\mathrm{As}(\mathrm{V})$ solutions $(2.0 \mathrm{mg} / \mathrm{L})$, the predicted maximum adsorption capacity of the ICZ, through the Langmuir model, was $0.68 \mathrm{mg}_{\mathrm{As}} / \mathrm{g}_{\text {zeolite, }}$ which decreased to 0.53 in the presence of sulfate (at $400 \mathrm{mg} / \mathrm{L}$ ) in the same experimental conditions. This support was chosen for field application, on the decontamination of mine drainage containing arsenic, cadmium and lead [126].

Beside iron oxide, MMZs with alumina and $\mathrm{MnO}_{2}$ have also been reported on the removal of arsenate or arsenite, and in some cases bimetallic oxide MMZs have been employed. Fe and Al natural clinoptilolite $\mathrm{MMZ}$ was reported to adsorb $\mathrm{As}(\mathrm{V})$ by Simsek et al. [66]. The authors claim that the maximum uptake of $5.86 \mathrm{mg}_{\text {As }} / \mathrm{g}_{\text {zeolite }}$ was achieved with the bimetallic Fe/Al oxide $\mathrm{MMZ}$, from a solution of $9.5 \mathrm{mg}_{\mathrm{As}} / \mathrm{L}$. $\mathrm{A} \mathrm{MnO}_{2}$-natural clinoptilolite MMZ was recently evaluated for arsenate removal from dilute solutions by Camacho, Parra and Deng. The authors evaluated $\mathrm{pH}$ and $\mathrm{As}(\mathrm{V})$ feed concentrations and concluded that the inclusion of $\mathrm{MnO}_{2}$ on the zeolite increased its sorption capacity and heterogeneity, as contrasted by the poor fitting obtained by the Langmuir model on the $\mathrm{MnO}_{2}-\mathrm{MMZ}$, compared to parent zeolite [127]. Maximum uptake was observed for a $50 \mu g_{\text {As }} / \mathrm{L}$ solution, at $2.5 \mu g_{\text {As }} / g_{\text {zeolite. }}$ The growing interest in zeolite synthesis from fly ash has also resulted in the application of an alumina-loaded cancrinite-type zeolite on the treatment of $\mathrm{As}(\mathrm{V})$ by Qiu and Zheng [128]. The authors reported a maximum uptake of $34.5 \mathrm{mg}$ As $/ \mathrm{g}_{\text {zeolite }}$ with this support. Table 2 presents an overlook on the achievements of different SMZs in the adsorption of $\mathrm{Cr}(\mathrm{VI})$ or $\mathrm{As}(\mathrm{V})$.

\subsection{Redox processes}

\subsubsection{Metal modified zeolites}

The modification of zeolites with metal ions that are redox agents for $\mathrm{Cr}(\mathrm{VI})$ was reported. Some known reducing agents for $\mathrm{Cr}(\mathrm{VI})$ also offer intrinsic capacity for being ion-exchanged in a zeolitic structure. That is the case of Fe(II) ions, which have been used on the modification of natural and synthetic zeolites to promote chromate reduction and removal. Kiser and Manning resorted to a $\mathrm{Fe}(\mathrm{II})$-modified synthetic $\mathrm{NaY}$ on the treatment of $\mathrm{Cr}(\mathrm{VI})$ solutions and observed that the reduced $\mathrm{Cr}$ (III) species, being susceptible for ion-exchange, readily displace additional Fe(II) from the zeolite exchange sites. This cooperative mechanism between $\mathrm{Cr}(\mathrm{III}) / \mathrm{Fe}(\mathrm{II})$ results in cation exchange with $\mathrm{Fe}(\mathrm{II})$, hence assisting additional $\mathrm{Cr}(\mathrm{VI})$ reduction. Furthermore, the authors commented that the presence of the $\mathrm{Al}-\mathrm{Si}-\mathrm{O}$ and $\mathrm{SiO}_{2}$ surfaces in the zeolite structure may assist the reaction of $\mathrm{Cr}(\mathrm{VI})$ with $\mathrm{Fe}(\mathrm{II})$ by providing 
a catalytic effect [130]. The reported maximum chromium uptake was $16 \mathrm{mg}_{\mathrm{Cr}} / \mathrm{g}_{\text {zeolite }}$ Other applications of Fe(II) MMZs for the treatment of chromate were reported by Huang and Zhang [131] and very recently by Lv et al. [132].

Some interesting variations to the former examples are also reported. The most directly related was presented by Lee et al. The authors started from a similarly prepared Fe(II) natural clinoptilolite zeolite (Pohang, Korea), but promoted reduction of the iron ions to the zerovalent state with sodium borohydride [133]. The authors used this support for the simultaneous treatment of diluted $\mathrm{Cd}(\mathrm{II})$ and $\mathrm{Cr}(\mathrm{VI})$ solutions. This support demonstrated reduction capacity for $\mathrm{Cr}(\mathrm{VI})$ while retaining the ion-exchange capacity for cadmium, although sorption equilibrium times differed significantly between the two metals. A more elaborated alternative has been proposed by Li et al., whom combined zerovalent iron particles with natural clinoptilolite via an hydrogel prepared with sodium silicate and sodium aluminate, which is cured, homogenized and later treated with HDTMA to form a combined iron MMZ-SMZ for the reduction and sorption of chromate [89]. The combined reduction/sorption of $\mathrm{Cr}(\mathrm{VI})$ resulted in an uptake of $780 \mu \mathrm{g}_{\mathrm{Cr}} / \mathrm{g}_{\text {support }}$ for the iron MMZ-SMZ, compared to $520 \mu \mathrm{g}_{\mathrm{Cr}} / \mathrm{g}_{\text {support }}$ for the equivalent SMZ obtained in the absence of zerovalent iron. The same system was successfully employed to the packing of columns for open-flow treatment of $\mathrm{Cr}(\mathrm{VI})$ solutions [88].

In terms of As(III) oxidation, few works report the use of zeolitic supports. A work from Anielak et al. did state that Mn-modified clinoptilolite was able to oxidize As(III) to $\mathrm{As}(\mathrm{V})$ [70]. Some other works report that $\mathrm{MnO}_{2}$ is reduced to $\mathrm{Mn}(\mathrm{II})$ by $\mathrm{As}(\mathrm{III})$, and this oxide has been successfully used to coat minerals such as sand or quartz [68]. Therefore, it is expectable that $\mathrm{MnO}_{2} \mathrm{MMZs}$ could also be of use on As(III) oxidation and treatment.

\subsubsection{Photocatalytic redox processes}

A recent publication by Shao et al. reported the photocatalytic reduction of $\mathrm{Cr}(\mathrm{VI})$ to $\mathrm{Cr}(\mathrm{III})$ by $\mathrm{ZSM}-5$ zeolite, compared to $\mathrm{ZnO}$ and in the presence or absence of oxalate [134]. The authors chose oxalate as a model for organic compounds in the environment. ZSM-5 zeolite showed pH-dependent photocatalytic activity in the reduction of $\mathrm{Cr}(\mathrm{VI})$, albeit being outperformed by $\mathrm{ZnO}$ in the same experimental conditions.

An interesting approach has been previously described by Kanthasamy and Larsen, whom prepared ZSM-5 zeolite hollow tubular structures doped with $\mathrm{Fe}(\mathrm{III})$ nitrate for the reduction of $\mathrm{Cr}(\mathrm{VI})$ [135]. The zeolitic tubes were synthesized from mesoporous silica, which acted both as a structural template and reagent, since it is consumed during the synthesis. Doping with $\mathrm{Fe}(\mathrm{III})$ was conducted in two distinct procedures: during synthesis, which leads to the encapsulation of $\mathrm{Fe}(\mathrm{III})$ ions within the hollow structure; or post-synthetically by ion-exchange. The dispersion of iron achieved with the first process was found to be greater, and ion-exchange promoted aggregation of iron particles on the surface, giving rise to subsequent leaching, which led to a decrease in activity of the ion-exchanged catalyst.

\subsubsection{Zeolites as supports for bioremediation of $\mathrm{Cr}$ and As oxyanions}

Hexavalent chromium reduction by biosorbents with subsequent removal of the formed $\mathrm{Cr}$ (III) ions by zeolites has been reported. The concept of combining bacterial capacity for biosorption of heavy metals with a zeolitic support was originally proposed by Neves and Tavares. The Arthrobacter viscosus bacterium supported on zeolites was extensively used for the treatment of $\mathrm{Cr}(\mathrm{VI})$ solutions, and several zeolites were succesfully employed as support (natural clinoptilolite or synthetic FAU, MFI, MOR and BEA zeolites) $[24,40,136-143]$. This bacterium is able to form a biofilm on the zeolitic surface, as reported by Lameiras et al. The authors found that the removal percentages obtained for the biofilm-laden zeolite sorbent are similar than those previously obtained using instead granular activated carbon (GAC) as support [144]. Typical uptake values for initial $\mathrm{Cr}(\mathrm{VI})$ concentration up to $100 \mathrm{mg} / \mathrm{L}$ range from 5 to $10 \mathrm{mg}_{\mathrm{Cr}} / \mathrm{g}_{\text {zeolite }}$ to $17.0 \mathrm{mg}_{\mathrm{Cr}} / \mathrm{g}_{\text {zeolite }}$ in latter reports, usually achieved with synthetic FAU zeolite and with higher biomass concentration [143]. This approach has already reached the stage of pilot-scale testing [145]. An Escherichia coli biofilm supported on NaY zeolite was also evaluated. The results obtained using this bacterium are similar to the obtained using Arthrobacter viscosus on identical conditions [24,146]. For an initial chromium concentration of $100 \mathrm{mg} / \mathrm{L}$, the uptake values found were around $4 \mathrm{mg} / \mathrm{g}_{\text {support }}$ for both bacteria. E. coli was also evaluated on natural clinoptilolite by Erdoğan et al., as well as other bacterial strains ( $B$. subtilis, S. aureus, S. epidermidis and $P$. aeuriginosa). Based on the fitting of the Langmuir adsorption model, the highest maximum uptake was achieved by the B. subtilis-clinoptilolite system, with $2.44 \mathrm{mg}_{\mathrm{Cr}} / \mathrm{g}_{\text {support }}[147]$.

Arsenite oxidation with bacteria supported on chabazite was investigated by Lièvremont et al. [83]. The authors tested a bacterial strain isolated from an arsenic-contaminated site, later identified as a $\beta$-Proteobacteria, in combination with some minerals (the referred chabazite zeolite, quartz sand and kutnahorite mineral) and concluded that the zeolite or quartz sand could be used in a first instance to support the biooxidation of As(III) on large-scale remediation of arsenic contamination. An indirect study reporting bio-oxidation of organic As(III) compounds on zeolitic supports was presented by Mattusch et al. The authors evaluated the decomposition of arsenobetaine, which is formed mainly by metabolization of arsenate in marine organisms such as fish, mollusks and crustaceans. While studying the decomposition of arsenobetaine with natural and synthetic clinoptilolite, the authors noticed the formation of degradation products from carbon-arsenic bond cleavage pathways using natural clinoptilolite, while the synthetic counterpart only revealed sorption properties. The authors traced back the decomposition to bacterial contamination of the natural clinoptilolite samples and referred possible presence of Leptospirillum ferrooxidans and Thiobacillus thiooxidans, while other species would be likely present. Although the purpose of this work was different, it showed the possibility of zeolite-bacteria systems to be also exploited on arsenic removal from organoarsenic compounds [148].

\section{Conclusion}

As it was presented in this paper, the versatility of zeolites is so ample that it offers interesting options to overcome their own natural limitation for anions, by conducting chemical modification or by tailoring of the matrix. The comparison between chromium and arsenic oxyanions also brings to light some interesting subtle physicochemical differences concerning their interaction with the environment and for the development of treatment/remediation procedures. Their differences are also highlighted through the interaction of $\mathrm{Cr}(\mathrm{VI}), \mathrm{As}(\mathrm{III})$ and $\mathrm{As}(\mathrm{V})$ with zeolites. To this respect, designing zeolite-based technologies for the treatment of each of these compounds further stresses the versatility of these materials

As adsorption processes are concerned, surfactant modification of the zeolite surface proved to be a straightforward process to obtain efficient supports, whereas surface functionalization, despite being a slightly more elaborated methodology, allows for considerable higher uptake values (notably for $\mathrm{Cr}$ ). These techniques are somewhat complementary in terms of achieving the same purpose from different zeolites, as SMZ require Al-rich zeolites while Al-poor zeolites are preferred for surface functionalization. Despite the special requirements of surface 
functionalization, the range of applications is larger than for SMZs, as it is possible to tailor the zeolite for multi-functionality (such as endowing magnetic properties to the support) or attributing specific selectivity for hexavalent chromium to the support, for the separation of $\mathrm{Cr}$ from other oxyanions in solution. Redox processes are also possible, provided zeolites are modified with either reducing or oxidizing agents (for $\mathrm{Cr}(\mathrm{VI})$ and $\mathrm{As}(\mathrm{III})$, respectively).

It is worthwhile to notice that some of earlier technologies such as SMZ are still of actual interest, since reports keep being presented. Also, some of the technologies are maturing into pilot-phase or even being field tested. It is reasonable to foresee that further modifications of zeolites will be investigated; either from environmentally aimed studies or from pure material science advance, keeping zeolite tailoring an open field.

\section{Acknowledgements}

Cristina Quintelas is thankful to Fundação para a Ciência e Tecnologia (FCT, Portugal) for funding the CEB researcher unit at the University of Minho and thanks the Project "Biolnd - Biotechnology and Bioengineering for improved Industrial and Agro-Food processes, REF. NORTE-07-0124-FEDER-000028" Co-funded by the Programa Operacional Regional do Norte (ON.2-O Novo Norte), QREN, FEDER for her reseach grant. Hugo Figueiredo would like to express his gratitude to FCT, Portugal, for the concession of his former PhD grant (ref. SFRH/BD/28201/2006). Cristina Quintelas would like to express her gratitude to FCT, Portugal, for the concession of her former PhD and Post-Doc grants (SFRH/BD/8646/2002 and SFRH/BPD/32113/2006, respectively). Authors are also thankful to Drs Isabel Neves and Teresa Tavares for their former supervision.

\section{References}

[1] B. Godlewska-Żyłkiewicz, Microorganisms in inorganic chemical analysis, Anal. Bioanal. Chem. 384 (2006) 114-123.

[2] M. Gavrilescu, Removal of heavy metals from the environment by biosorption, Eng. Life Sci. 4 (2004) 219-232.

[3] O. Hernandez-Ramirez, S.M. Holmes, Novel and modified materials for wastewater treatment applications, J. Mater. Chem. 18 (2008) 2751-2761

[4] S.E. Bailey, T.J. Olin, R.M. Bricka, D.D. Adrian, A review of potentially low-cost sorbents for heavy metals, Water Res. 33 (1999) 2469-2479.

[5] E. Erdem, N. Karapinar, R. Donat, The removal of heavy metal cations by natural zeolites, J. Colloid Interface Sci. 280 (2004) 309-314.

[6] S. Babel, T.A. Kurniawan, Low-cost adsorbents for heavy metals uptake from contaminated water: a review, J. Hazard. Mater. 97 (2003) 219-243.

[7] A.M. Yusof, N.A.N.N. Malek, Removal of $\mathrm{Cr}(\mathrm{VI})$ and $\mathrm{As}(\mathrm{V})$ from aqueous solutions by HDTMA-modified zeolite Y, J. Hazard. Mater. 162 (2009) 1019-1024.

[8] S. Matijasevic, A. Dakovic, M. Tomasevic-Canovic, M. Stojanovic, D. Iles, Uranium(VI) adsorption on surfactant modified heulandite/clinoptilolite rich tuff, J. Serbian Chem. Soc. 71 (2006) 1323-1331.

[9] J. Warchoł, P. Misaelides, R. Petrus, D. Zamboulis, Preparation and application of organo-modified zeolitic material in the removal of chromates and iodides, J. Hazard. Mater. 137 (2006) 1410-1416.

[10] J.-W. Choi, S.-Y. Lee, S.-H. Lee, J.-E. Kim, K.-Y. Park, D.-J. Kim, S.-W. Hong, Comparison of surface-modified adsorbents for phosphate removal in water, Water Air Soil Pollut. 223 (2012) 2881-2890.

[11] M.S. Onyango, M. Masukume, A. Ochieng, F. Otieno, Functionalised natural zeolite and its potential for treating drinking water ontaining excess amount of nitrate, Water SA 36 (2010) 655-662.

[12] H. Figueiredo, B. Silva, C. Quintelas, M.F.R. Pereira, I.C. Neves, T. Tavares, Biosorption of hexavalent chromium based on modified y zeolites obtained by alkaline treatment, Environ. Eng. Manage. J. 9 (2010) 305-311.

[13] A. Corma, H. Garcia, Supramolecular host-guest systems in zeolites prepared by ship-in-a-bottle synthesis, Eur. J. Inorg. Chem. 2004 (2004) 1143-1164.

[14] R. Le Van Mao, S. Xiao, A. Ramsaran, J. Yao, Selective removal of silicon from zeolite frameworks using sodium carbonate, J. Mater. Chem. 4 (1994) 605-610.

[15] V.J. Inglezakis, The concept of capacity in zeolite ion-exchange systems, J.Colloid Interface Sci. 281 (2005) 68-79.

[16] G.V.Tsitsishvili, T.G. Andronikashvili, G.N. Kirov, L.D. Filizova, Natural Zeolites, Ellis Horwood, Chichester, UK, 1992.

[17] A. Agrawal, V. Kumar, B.D. Pandey, Remediation options for the treatment of electroplating and leather tanning effluent containing chromium - a review, Miner. Process. Extract. Metall. Rev. 27 (2006) 99-130.
[18] H. Yin, B. He, X. Lu, H. Peng, J. Ye, F. Yang, Improvement of chromium biosorption by UV- $\mathrm{HNO}_{2}$ cooperative mutagenesis in Candida utilis, Water Res. 42 (2008) 3981-3989.

[19] R.N. Horton, W.A. Apel, V.S. Thompson, P.P. Sheridan, Low temperature reduction of hexavalent chromium by a microbial enrichment consortium and a novel strain of Arthrobacter aurescens, BMC Microbiol. 6 (2006) 5

[20] N.Y. Tsibakhashvili, L.M. Mosulishvili, T.L. Kalabegishvili, E.I. Kirkesali, M.V. Frontasyeva, E.V. Pomyakushina, S.S. Pavlov, H.-Y.N. Holman, ENAA studies of chromium uptake by Arthrobacter oxydans, J. Radioanal. Nucl. Chem. 259 (2004) 527-531.

[21] G.J. Puzon, A.G. Roberts, D.M. Kramer, L. Xun, Formation of soluble organochromium(III) complexes after chromate reduction in the presence of cellular organics, Environ. Sci. Technol. 39 (2005) 2811-2817.

[22] B.M. Weckhuysen, I.E. Wachs, R.A. Schoonheydt, Surface chemistry and spectroscopy of chromium in inorganic oxides, Chem. Rev. 96 (1996) 3327-3350.

[23] G.J. Puzon, R.K. Tokala, H. Zhang, D. Yonge, B.M. Peyton, L. Xun, Mobility and recalcitrance of organo-chromium(III) complexes, Chemosphere 70 (2008) 2054-2059.

[24] B. Silva, H. Figueiredo, C. Quintelas, I. Neves, T. Tavares, Zeolites as supports for the biorecovery of hexavalent and trivalent chromium, Microporous Mesoporous Mater. 116 (2008) 555-560.

[25] B. Fonseca, A. Teixeira, H. Figueiredo, T. Tavares, Modelling of the $\mathrm{Cr}(\mathrm{VI})$ transport in typical soils of the North of Portugal, J. Hazard. Mater. 167 (2009) $752-762$.

[26] T.L. Kalabegishvili, N.Y. Tsibakhashvili, H.-Y.N. Holman, Electron spin resonance study of chromium(V) formation and decomposition by basaltinhabiting bacteria, Environ. Sci. Technol. 37 (2003) 4678-4684.

[27] C. Quintelas, B. Fernandes, J. Castro, H. Figueiredo, T. Tavares, Biosorption of $\mathrm{Cr}(\mathrm{VI})$ by three different bacterial species supported on granular activated carbon: a comparative study, J. Hazard. Mater. 153 (2008) 799-809.

[28] A.K. Sengupta, D. Clifford, Important process variables in chromate ion exchange, Environ. Sci. Technol. 20 (1986) 149-155.

[29] B.K. Mandal, K.T. Suzuki, Arsenic round the world: a review, Talanta 58 (2002) $201-235$.

[30] D. Melamed, Monitoring arsenic in the environment: a review of science and technologies with the potential for field measurements, Anal. Chim. Acta 532 (2005) 1-13.

[31] D. Lièvremont, P.N. Bertin, M.-C. Lett, Arsenic in contaminated waters: biogeochemical cycle, microbial metabolism and biotreatment processes, Biochimie 91 (2009) 1229-1237.

[32] P. Mondal, S. Bhowmick, D. Chatterjee, A. Figoli, B. Van der Bruggen, Remediation of inorganic arsenic in groundwater for safe water supply: a critical assessment of technological solutions, Chemosphere 92 (2013) 157-170.

[33] S.C. Wilson, P.V. Lockwood, P.M. Ashley, M. Tighe, The chemistry and behaviour of antimony in the soil environment with comparisons to arsenic: a critical review, Environ. Pollut. 158 (2010) 1169-1181.

[34] D. Mohan, C.U. Pittman, Arsenic removal from water/wastewater using adsorbents - a critical review, J. Hazard. Mater. 142 (2007) 1-53.

[35] H.A. Andrianisa, A. Ito, A. Sasaki, J. Aizawa, T. Umita, Biotransformation of arsenic species by activated sludge and removal of bio-oxidised arsenate from wastewater by coagulation with ferric chloride, Water Res. 42 (2008) 4809-4817

[36] C. Covarrubias, R. Arriagada, J. Yáñez, R. García, M. Angélica, S.D. Barros, P. Arroyo, E.F. Sousa-Aguiar, Removal of chromium(III) from tannery effluents, using a system of packed columns of zeolite and activated carbon, J. Chem. Technol. Biotechnol. 80 (2005) 899-908.

[37] C. Covarrubias, R. García, R. Arriagada, J. Yánez, M.T. Garland, Cr(III) exchange on zeolites obtained from kaolin and natural mordenite, Microporous Mesoporous Mater. 88 (2006) 220-231.

[38] S.M. Dal Bosco, R.S. Jimenez, W.A. Carvalho, Removal of toxic metals from wastewater by Brazilian natural scolecite, J.Colloid Interface Sci. 281 (2005) 424-431

[39] F. Gazola, M. Pereira, M. Barros, E. Silva, P. Arroyo, Removal of $\mathrm{Cr}^{3+}$ in fixed bed using zeolite NaY, Chem. Eng. J. 117 (2006) 253-261.

[40] M.T. Tavares, C. Quintelas, H. Figueiredo, I. Neves, Comparative study between natural and artificial zeolites as supports for biosorption systems maria teresa tavares, Mater. Sci. Forum. 516 (2006) 1294-1298.

[41] M. Vaca Mier, R. López Callejas, R. Gehr, B.E. Jiménez Cisneros, P.J.J. Alvarez, Heavy metal removal with mexican clinoptilolite: multi-component ionic exchange, Water Res. 35 (2001) 373-378.

[42] S.A. Boyd, J.-F. Lee, M.M. Mortland, Attenuating organic contaminant mobility by soil modification, Nature 333 (1988) 345-347.

[43] G.M. Haggerty, R.S. Bowman, Sorption of chromate and other inorganic anions by organo-zeolite, Environ. Sci. Technol. 28 (1994) 452-458.

[44] Z. Sadaoui, S. Hemidouche, O. Allalou, Removal of hexavalent chromium from aqueous solutions by micellar compounds, Desalination 249 (2009) $768-773$.

[45] R.S. Bowman, Applications of surfactant-modified zeolites to environmental remediation, Microporous Mesoporous Mater. 61 (2003) 43-56.

[46] Z. Li, R.S. Bowman, Counterion effects on the sorption of cationic surfactant and chromate on natural clinoptilolite, Environ. Sci. Technol. 31 (1997) 2407-2412.

[47] I. García-Sosa, M. Solache-Ríos, M. Olguín, J. Jiménez-Becerril, Preparation and characterization of a Mexican organo clinoptilolite-heulandite mineral and its evaluation for the sorption of cadmium and cobalt, J. Radioanal. Nucl. Chem. 256 (2003) 273-277. 
[48] J. Schick, P. Caullet, J.-L. Paillaud, J. Patarin, S. Freitag, C. Mangold-Callarec, Phosphate uptake from water on a surfactant-modified zeolite and Cazeolites, J. Porous Mater. 19 (2011) 405-414.

[49] W. Mozgawa, M. Król, T. Bajda, IR spectra in the studies of anion sorption on natural sorbents, J. Mol. Struct. 993 (2011) 109-114.

[50] C.B. Vidal, G.S.C. Raulino, A.L. Barros, A.C.A. Lima, J.P. Ribeiro, M.J.R. Pires, R.F. Nascimento, BTEX removal from aqueous solutions by HDTMA-modified Y zeolite, J. Environ. Manage. 112 (2012) 178-185.

[51] D. Krajišnik, A. Daković, A. Malenović, L. Djekić, M. Kragović, V. Dobričić, J. Milíc, An investigation of diclofenac sodium release from cetylpyridinium chloride-modified natural zeolite as a pharmaceutical excipient, Microporous Mesoporous Mater. 167 (2013) 94-101.

[52] J. Hrenovic, M. Rozic, L. Sekovanic, A. Anic-Vucinic, Interaction of surfactantmodified zeolites and phosphate accumulating bacteria, J. Hazard. Mater. 156 (2008) 576-582.

[53] Removing viruses using zeolites, Membr. Technol. 2002 (2002) 5.

[54] T. Kawai, K. Tsutsumi, Reactivity of silanol groups on zeolite surfaces, Colloid Polym. Sci. 276 (1998) 992-998.

[55] K. Moller, T. Bein, Inclusion chemistry in periodic mesoporous hosts, Chem. Mater. 10 (1998) 2950-2963.

[56] K. Barquist, S. Larsen, Chromate adsorption on amine-functionalized nanocrystalline silicalite-1, Microporous Mesoporous Mater. 116 (2008) 365-369.

[57] K.F. Lam, K.L. Yeung, G. Mckay, Selective mesoporous adsorbents for $\mathrm{Cr}_{2} \mathrm{O}_{7}{ }^{2-}$ and $\mathrm{Cu}^{2+}$ separation, Microporous Mesoporous Mater. 100 (2007) 191-201.

[58] D.M. Bibby, N.B. Milestone, L.P. Aldridge, Silicalite-2, a silica analogue of the aluminosilicate zeolite ZSM-11, Nature 280 (1979) 664-665.

[59] O. Vassylyev, J. Chen, G.S. Hall, J.G. Khinast, Efficient surface functionalization of zeolites via esterification, Microporous Mesoporous Mater. 92 (2006) $101-108$.

[60] D. Brühwiler, G. Calzaferri, Selective functionalization of the external surface of zeolite L, Comptes Rendus Chim. 8 (2005) 391-398.

[61] W. Song, J.F. Woodworth, V.H. Grassian, S.C. Larsen, Microscopic and macroscopic characterization of organosilane-functionalized nanocrystalline NaZSM-5, Langmuir 21 (2005) 7009-7014.

[62] K. Barquist, S.C. Larsen, Chromate adsorption on bifunctional, magnetic zeolite composites, Microporous Mesoporous Mater. 130 (2010) $197-202$.

[63] L.C.A. Oliveira, D.I. Petkowicz, A. Smaniotto, S.B.C. Pergher, Magnetic zeolites: a new adsorbent for removal of metallic contaminants from water, Water Res. 38 (2004) 3699-3704.

[64] P. Wu, Y. Zhou, Simultaneous removal of coexistent heavy metals from simulated urban stormwater using four sorbents: a porous iron sorbent and its mixtures with zeolite and crystal gravel, J. Hazard. Mater. 168 (2009) 674-680.

[65] S. Marchetti, M. Cagnoli, A. Alvarez, J. Bengoa, R. Mercader, A. Yeramián, Study of the Fe/zeolite-L system: Part I. Characterization of iron species and their structural properties, Appl. Surf. Sci. 165 (2000) 91-99.

[66] E.B. Simsek, E. Özdemir, U. Beker, Zeolite supported mono- and bimetallic oxides: promising adsorbents for removal of $\mathrm{As}(\mathrm{V})$ in aqueous solutions, Chem. Eng. J. 220 (2013) 402-411.

[67] K. Barquist, S.C. Larsen, Chromate adsorption on bifunctional, magnetic zeolite composites, Microporous Mesoporous Mater. 130 (2010) 197-202.

[68] M. Bissen, F.H. Frimmel, Arsenic - a review: Part II. Oxidation of arsenic and its removal in water treatment, Acta Hydrochim. Hydrobiol. 31 (2003) 97-107.

[69] C.E. Barrera-Díaz, V. Lugo-Lugo, B. Bilyeu, A review of chemical, electrochemical and biological methods for aqueous $\mathrm{Cr}(\mathrm{VI})$ reduction, J. Hazard. Mater. 223-224 (2012) 1-12.

[70] A.M. Anielak, R. Świderska-Dąbrowska, A. Majewski, Removal of arsenic from underground waters on modified clinoptilolite, in: Environ. Eng. - Proc. 2nd Natl. Congr. Environ. Eng., 2007, pp. 221-225.

[71] X. Guan, J. Du, X. Meng, Y. Sun, B. Sun, Q. Hu, Application of titanium dioxide in arsenic removal from water: a review, J. Hazard. Mater. 215-216 (2012) $1-16$.

[72] D. Kratochvil, B. Volesky, Advances in the biosorption of heavy metals, Trends Biotechnol. 16 (1998) 291-300.

[73] P. Le Cloirec, Y. Andrè, C. Faur-Brasquet, C. Gérente, Engineered biofilms for metal ion removal, Rev. Environ. Sci. Bio/Technol. 2 (2003) 177-192.

[74] E. Kulczycki, F.G. Ferris, D. Fortin, Impact of cell wall structure on the behavior of bacterial cells as sorbents of cadmium and lead, Geomicrobiol. J. 19 (2002) 553-565.

[75] V.Somasundaram, L. Philip, S.M. Bhallamudi, Experimental and mathematical modeling studies on $\mathrm{Cr}(\mathrm{VI})$ reduction by $\mathrm{CRB}$, SRB and IRB, individually and in combination, J. Hazard. Mater. 172 (2009) 606-617.

[76] J. Yang, M. He, G. Wang, Removal of toxic chromate using free and immobilized $\mathrm{Cr}(\mathrm{VI})$-reducing bacterial cells of intrasporangium sp. Q5-1, World J. Microbiol. Biotechnol. 25 (2009) 1579-1587.

[77] R. Elangovan, L. Philip, K. Chandraraj, Hexavalent chromium reduction by free and immobilized cell-free extract of Arthrobacter rhombi-RE, Appl. Biochem. Biotechnol. 160 (2010) 81-97.

[78] M.A. Polti, M.J. Amoroso, C.M. Abate, Intracellular chromium accumulation by Streptomyces sp. MC1, Water. Air. Soil Pollut. 214 (2011) 49-57.

[79] A.A.L. Hasin, S.J. Gurman, L.M. Murphy, A. Perry, T.J. Smith, P.H.E. Gardiner, Remediation of chromium(VI) by a methane-oxidizing bacterium, Environ. Sci. Technol. 44 (2010) 400-405.
[80] D. Park, S.-R. Lim, Y.-S. Yun, J.M. Park, Reliable evidences that the removal mechanism of hexavalent chromium by natural biomaterials is adsorptioncoupled reduction, Chemosphere 70 (2007) 298-305.

[81] D. Park, Y.-S. Yun, J.Y. Kim, J.M. Park, How to study Cr(VI) biosorption: use of fermentation waste for detoxifying $\mathrm{Cr}(\mathrm{VI})$ in aqueous solution, Chem. Eng. J. 136 (2008) 173-179.

[82] Z. Lin, Y. Zhu, T. Kalabegishvili, N. Tsibakhashvili, H. Holman, Effect of chromate action on morphology of basalt-inhabiting bacteria, Mater. Sci. Eng. C 26 (2006) 610-612

[83] D. Lièvremont, M. N'negue, P. Behra, M.-C. Lett, Biological oxidation of arsenite: batch reactor experiments in presence of kutnahorite and chabazite, Chemosphere 51 (2003) 419-428.

[84] S.-L. Tsai, S. Singh, W. Chen, Arsenic metabolism by microbes in nature and the impact on arsenic remediation, Curr. Opin. Biotechnol. 20 (2009) 659-667.

[85] D. Park, Y.-S. Yun, J.M. Park, The past, present, and future trends of biosorption, Biotechnol. Bioprocess Eng. 15 (2010) 86-102.

[86] H. Yoshitake, T. Yokoi, T. Tatsumi, Adsorption of chromate and arsenate by amino-functionalized MCM-41 and SBA-1, Chem. Mater. 14 (2002) 4603-4610.

[87] P. Kumar, P.D. Jadhav, S.S. Rayalu, S. Devotta, Surface-modified zeolite-A for sequestration of arsenic and chromium anions, Curr. Sci. 92 (2007) 512-517.

[88] Z. Li, H. Kirk Jones, P. Zhang, R.S. Bowman, Chromate transport through columns packed with surfactant-modified zeolite/zero valent iron pellets, Chemosphere 68 (2007) 1861-1866.

[89] Z. Li, H.K. Jones, R.S. Bowman, R. Helferich, Enhanced reduction of chromate and PCE by pelletized surfactant-modified zeolite/zerovalent iron, Environ. Sci. Technol. 33 (1999) 4326-4330.

[90] Y. Kato, N. Mita, The removal of antimony wastewaters by using natural zeolites, in: Proc. TMS Fall Extract. Process. Conf., 1999, pp. 2459-2468.

[91] M.S. Onyango, D. Kuchar, M. Kubota, H. Matsuda, Adsorptive removal of phosphate ions from aqueous solution using synthetic zeolite, Ind. Eng. Chem. Res. 46 (2007) 894-900.

[92] U. Wingenfelder, G. Furrer, R. Schulin, Sorption of antimonate by HDTMAmodified zeolite, Microporous Mesoporous Mater. 95 (2006) 265-271.

[93] S. Shevade, R.G. Ford, Use of synthetic zeolites for arsenate removal from pollutant water, Water Res. 38 (2004) 3197-3204.

[94] P. Chutia, S. Kato, T. Kojima, S. Satokawa, Arsenic adsorption from aqueous solution on synthetic zeolites, J. Hazard. Mater. 162 (2009) 440-447.

[95] M.P. Elizalde-González, J. Mattusch, W.-D. Einicke, R. Wennrich, Sorption on natural solids for arsenic removal, Chem. Eng. J. 81 (2001) 187-195.

[96] P. Chutia, S. Kato, T. Kojima, S. Satokawa, Adsorption of As(V) on surfactantmodified natural zeolites, J. Hazard. Mater. 162 (2009) 204-211.

[97] P. Misaelides, V.A. Nikashina, A. Godelitsas, P.A. Gembitskii, E.M. Kats, Sorption of $\mathrm{As}(\mathrm{V})$-anions from aqueous solutions by organo-modified natural zeolitic materials, J. Radioanal. Nucl. Chem. 227 (1998) 183-186.

[98] C. Covarrubias, R. García, J. Yánez, R. Arriagada, Preparation of CPB-modified FAU zeolite for the removal of tannery wastewater contaminants, J. Porous Mater. 15 (2007) 491-498.

[99] Z. Li, H. Hong, Retardation of chromate through packed columns of surfactantmodified zeolite, J. Hazard. Mater. 162 (2009) 1487-1493.

[100] M. Ghiaci, R. Kia, A. Abbaspur, F. Seyedeyn-Azad, Adsorption of chromate by surfactant-modified zeolites and MCM-41 molecular sieve, Sep. Purif. Technol. 40 (2004) 285-295.

[101] Y.Zeng, H. Woo, G. Lee, J. Park, Removal of chromate from water using surfactant modified Pohang clinoptilolite and Haruna chabazite, Desalination 257 (2010) 102-109.

[102] R. Leyva-Ramos, A. Jacobo-Azuara, P. Diaz-Flores, R. Guerrero-Coronado, J Mendoza-Barron, M. Berber-Mendoza, Adsorption of chromium(VI) from an aqueous solution on a surfactant-modified zeolite, Colloids Surf. A: Physicochem. Eng. Asp. 330 (2008) 35-41.

[103] A.I. Pérez Cordoves, M. Granda Valdés, J.C. Torres Fernández, G. Pina Luis, J.A. García-Calzón, M.E. Díaz García, Characterization of the binding site affinity distribution of a surfactant-modified clinoptilolite, Microporous Mesoporous Mater. 109 (2008) 38-48.

[104] A.G. Thanos, E. Katsou, S. Malamis, K. Psarras, E. Pavlatou, K.J. Haralambous, Evaluation of modified mineral performance for chromate sorption from aqueous solutions, Chem. Eng. J. 211-212 (2012) 77-88.

[105] Z. Li, R. Beachner, Z. McManama, H. Hanlie, Sorption of arsenic by surfactantmodified zeolite and kaolinite, Microporous Mesoporous Mater. 105 (2007) 291-297.

[106] Y. Zeng, H. Woo, G. Lee, J. Park, Adsorption of $\mathrm{Cr}(\mathrm{VI})$ on hexadecylpyridinium bromide (HDPB) modified natural zeolites, Microporous Mesoporous Mater. 130 (2010) 83-91.

[107] P. Misaelides, D. Zamboulis, P. Sarridis, J. Warchoł, A. Godelitsas, Chromium (VI) uptake by polyhexamethylene-guanidine-modified natural zeolitic materials, Microporous Mesoporous Mater. 108 (2008) 162-167.

[108] V. Campos, L.C. Morais, P.M. Buchler, Removal of chromate from aqueous solution using treated natural zeolite, Environ. Geol. 52 (2006) 1521-1525.

[109] V. Campos, P.M. Buchler, Anionic sorption onto modified natural zeolites using chemical activation, Environ. Geol. 52 (2006) 1187-1192.

[110] M. Noroozifar, M. Khorasani-Motlagh, M.N. Gorgij, H.R. Naderpour, Adsorption behavior of $\mathrm{Cr}(\mathrm{VI})$ on modified natural zeolite by a new bolaform $\mathrm{N}, \mathrm{N}, \mathrm{N}, \mathrm{N}^{\prime}, \mathrm{N}^{\prime}, \mathrm{N}^{\prime}$-hexamethyl-1,9-nonanediammonium dibromide reagent, J. Hazard. Mater. 155 (2008) 566-571. 
[111] A.A. Shyaa, O.A. Hasan, A.M. Abbas, Synthesis and characterization of polyaniline/zeolite nanocomposite for the removal of chromium(VI) from aqueous solution, J. Saudi Chem. Soc. (2012), in press.

[112] Y. Román-Leshkov, M. Moliner, M.E. Davis, Hybrid organic-inorganic solids that show shape selectivity, Chem. Mater. 22 (2010) 2646-2652.

[113] G.E. Fryxell, J. Liu, T.A. Hauser, Z. Nie, K.F. Ferris, S. Mattigod, M. Gong, R.T. Hallen, Design and synthesis of selective mesoporous anion traps, Chem. Mater. 11 (1999) 2148-2154.

[114] T. Yokoi, T. Tatsumi, H. Yoshitake, Fe(3+) coordinated to amino-functionalized MCM-41: an adsorbent for the toxic oxyanions with high capacity, resistibility to inhibiting anions, and reusability after a simple treatment, J. Colloid Interface Sci. 274 (2004) 451-457.

[115] X. Chen, K.F. Lam, Q. Zhang, B. Pan, M. Arruebo, K.L. Yeung, Synthesis of highly selective magnetic mesoporous adsorbent, J. Phys. Chem. C 113 (2009) 9804-9813

[116] H. Faghihian, R.S. Bowman, Adsorption of chromate by clinoptilolite exchanged with various metal cations, Water Res. 39 (2005) 1099-1104.

[117] T. Bolortamir, R. Egashira, Removal of hexavalent chromium from model tannery wastewater by adsorption using mongolian natural zeolite, J. Chem. Eng. Japan 41 (2008) 1003-1009.

[118] Y.-H. Xu, A. Ohki, S. Maeda, Removal of arsenate, phosphate, and fluoride ions by aluminium-loaded Shirasu-zeolite, Toxicol. Environ. Chem. 76 (2000) $111-124$.

[119] Y. Xu, A. Ohki, S. Maeda, Adsorption of $\operatorname{arsenic}(\mathrm{V})$ by use of aluminium-loaded Shirasu-zeolites, Chem. Lett. 27 (1998) 1015-1016.

[120] Y. Xu, T. Nakajima, A. Ohki, Adsorption and removal of arsenic(V) from drinking water by aluminum-loaded Shirasu-zeolite, J. Hazard. Mater. 92 (2002) 275-287.

[121] M. Šiljeg, L. Foglar, I. Gudelj, The removal of arsenic from water with natura and modified clinoptilolite, Chem. Ecol. 28 (2012) 75-87.

[122] K. Payne, T. Abdel-Fattah, Adsorption of arsenate and arsenite by iron-treated activated carbon and zeolites: effects of $\mathrm{pH}$, temperature, and ionic strength, J. Environ. Sci. Health A 40 (2005) 723-749.

[123] M.J. Jiménez-Cedillo, M.T. Olguín, C. Fall, Adsorption kinetic of arsenates as water pollutant on iron, manganese and iron-manganese-modified clinoptilolite-rich tuffs, J. Hazard. Mater. 163 (2009) 939-945.

[124] G. Du, Z. Li, L. Liao, R. Hanson, S. Leick, N. Hoeppner, W.-T. Jiang, Cr(VI) retention and transport through Fe(III)-coated natural zeolite, J. Hazard. Mater. 221-222 (2012) 118-123

[125] C.-S. Jeon, K. Baek, J.-K. Park, Y.-K. Oh, S.-D. Lee, Adsorption characteristics of As(V) on iron-coated zeolite, J. Hazard. Mater. 163 (2009) 804-808.

[126] C.-S. Jeon, S.-W. Park, K. Baek, J.-S. Yang, J.-G. Park, Application of iron-coated zeolites (ICZ) for mine drainage treatment, Korean J. Chem. Eng. 29 (2012) $1171-1177$

[127] L.M. Camacho, R.R. Parra, S. Deng, Arsenic removal from groundwater by $\mathrm{MnO}_{2}$-modified natural clinoptilolite zeolite: effects of $\mathrm{pH}$ and initial feed concentration, J. Hazard. Mater. 189 (2011) 286-293.

[128] W. Qiu, Y. Zheng, Arsenate removal from water by an alumina-modified zeolite recovered from fly ash, J. Hazard. Mater. 148 (2007) 721-726.

[129] M.J. Jiménez-Cedillo, M.T. Olguín, C. Fall, A. Colín, Adsorption capacity of ironor iron-manganese-modified zeolite-rich tuffs for As(III) and As(V) water pollutants, Appl. Clay Sci. 54 (2011) 206-216.

[130] J.R. Kiser, B.A. Manning, Reduction and immobilization of chromium(VI) by iron(II)-treated faujasite, J. Hazard. Mater. 174 (2010) 167-174.

[131] Y.J. Huang, H.Z. Zhang, Experiment study on treatment of chromium(VI)containing groundwater by modified synthetic zeolite, Adv. Mater. Res. 430-432 (2012) 1253-1256.
[132] G. Lv, Z. Li, W.-T. Jiang, C. Ackley, N. Fenske, N. Demarco, Removal of Cr(VI) from water using Fe(II)-modified natural zeolite, Chem. Eng. Res. Des. 92 (2014) 384-390.

[133] S. Lee, K. Lee, J. Park, Simultaneous removal of Cd and Cr(VI) using Fe-loaded zeolite, J. Environ. Eng. 132 (2006) 445-450

[134] D. Shao, X. Wang, Q. Fan, Photocatalytic reduction of $\mathrm{Cr}(\mathrm{VI})$ to $\mathrm{Cr}(\mathrm{III})$ in solution containing $\mathrm{ZnO}$ or ZSM-5 zeolite using oxalate as model organic compound in environment, Microporous Mesoporous Mater. 117 (2009) 243-248.

[135] R. Kanthasamy, S.C. Larsen, Visible light photoreduction of $\mathrm{Cr}(\mathrm{VI})$ in aqueous solution using iron-containing zeolite tubes, Microporous Mesoporous Mater. 100 (2007) 340-349.

[136] H. Figueiredo, I.C. Neves, C. Quintelas, T. Tavares, M. Taralunga, J. Mijoin, P. Magnoux, Oxidation catalysts prepared from biosorbents supported on zeolites, Appl. Catal. B: Environ. 66 (2006) 274-280.

[137] H. Figueiredo, B. Silva, C. Quintelas, I.C. Neves, T. Tavares, Biosorption of Cr V supported on mordenite zeolite, in: M. Mota, E.C. Ferreira (Eds.), Proc. 10th Int. Chem. Biol. Eng. Conf. - CHEMPOR 2008, University of Minho, Biological Engineering Department, 2008, p. 2256.

[138] B. Silva, H. Figueiredo, C. Quintelas, I.C. Neves, T. Tavares, Iron and chromium removal from binary solutions of $\mathrm{Fe}(\mathrm{III}) / \mathrm{Cr}(\mathrm{III})$ and $\mathrm{Fe}(\mathrm{III}) / \mathrm{Cr}(\mathrm{VI})$ by biosorbents supported on zeolites, Mater. Sci. Forum. 588 (2008) 463-467.

[139] B. Silva, H. Figueiredo, I.C. Neves, T. Tavares, The role of $\mathrm{pH}$ on $\mathrm{Cr}$ (VI) reduction and removal by Arthrobacter viscosus, Int. J. Chem. Biomol. Eng. 43 (2009) 59-62.

[140] H. Figueiredo, B. Silva, C. Quintelas, I.C. Neves, T. Tavares, Effect of the supporting zeolite structure on $\mathrm{Cr}$ biosorption: performance of a single step reactor and of a sequential batch reactor - a comparison study, Chem. Eng. J. 163 (2010) 22-27.

[141] C. Quintelas, V.B. Silva, B. Silva, H. Figueiredo, T. Tavares, Optimization of production of extracellular polymeric substances by Arthrobacter viscosus and their interaction with a $13 \mathrm{X}$ zeolite for the biosorption of $\mathrm{Cr}(\mathrm{VI})$, Environ. Technol. 14 (2011) 1541-1549.

[142] B. Silva, H. Figueiredo, O.S.G.P. Soares, M.F.R. Pereira, J.L. Figueiredo, A.E. Lewandowska, M.A. Bañares, I.C. Neves, T. Tavares, Evaluation of ion exchange-modified $\mathrm{Y}$ and ZSM5 zeolites in $\mathrm{Cr}(\mathrm{VI})$ biosorption and catalytic oxidation of ethyl acetate, Appl. Catal. B: Environ. 117-118 (2012) 406-413.

[143] B. Silva, H. Figueiredo, C. Quintelas, I.C. Neves, T. Tavares, Improved biosorption for $\mathrm{Cr}(\mathrm{VI})$ reduction and removal by Arthrobacter viscosus using zeolite, Int. Biodeterior. Biodegrad. 74 (2012) 116-123.

[144] S. Lameiras, C. Quintelas, T. Tavares, Biosorption of $\mathrm{Cr}(\mathrm{VI})$ using a bacteria biofilm supported on granular activated carbon and on zeolite, Bioresour. Technol. 99 (2008) 801-806.

[145] M. Pazos, M. Branco, I.C. Neves, M.A. Sanromán, T. Tavares, Removal of Cr(VI) from aqueous solutions by a bacterial biofilm supported on zeolite: optimisation of the operational conditions and scale-up of the bioreactor, Chem. Eng. Technol. 33 (2010) 2008-2014.

[146] C. Quintelas, Z. Rocha, B. Silva, B. Fonseca, H. Figueiredo, T. Tavares, Biosorptive performance of an Escherichia coli biofilm supported on zeolite NaY for the removal of $\mathrm{Cr}(\mathrm{VI}), \mathrm{Cd}(\mathrm{II}), \mathrm{Fe}(\mathrm{III})$ and $\mathrm{Ni}(\mathrm{II})$, Chem. Eng. J. 152 (2009) 110-115

[147] B.C. Erdoğan, S. Ülkü, Cr(VI) sorption by using clinoptilolite and bacteria loaded clinoptilolite rich mineral, Microporous Mesoporous Mater. 152 (2012) 253-261.

[148] J. Mattusch, M.P. Elizalde-González, M.A. Pérez-Cruz, J. Ondruschka, R. Wennrich, Transformation of arsenobetaine and growth of bacteria on zeolitic tuffs, Eng. Life Sci. 8 (2008) 575-581. 